\title{
Foes or Friends? Bacteria Enriched in the Tumor Microenvironment of Colorectal Cancer
}

\author{
Siyang $\mathrm{Xu}^{\dagger}{ }^{\dagger}$, Wen Yin ${ }^{+} \mathbb{D}$, Yuling Zhang, Qimei Lv, Yijun Yang and Jin $\mathrm{He} * \mathbb{1}$ \\ State Key Laboratory of Agricultural Microbiology, College of Life Science and Technology, Huazhong Agricultural \\ University, Wuhan 430070, Hubei, China; xusiyangxsy@gmail.com (S.X.); yinwen@mail.hzau.edu.cn (W.Y.); \\ yulingzhang@webmail.hzau.edu.cn (Y.Z.); qimeil2017@163.com (Q.L.); yangyijuna@163.com (Y.Y.) \\ * Correspondence: hejin@mail.hzau.edu.cn \\ + These authors contributed equally to this work.
}

Received: 9 January 2020; Accepted: 4 February 2020; Published: 6 February 2020

\begin{abstract}
Colorectal cancer (CRC) is the second most commonly diagnosed cancer and the third cause of cancer death in the world, while intestinal microbiota is a community of microbes living in human intestine that can potentially impact human health in many ways. Accumulating evidence suggests that intestinal microbiota, especially that from the intestinal bacteria, play a key role in the CRC development; therefore, identification of bacteria involved in CRC development can provide new targets for the CRC diagnosis, prevention, and treatment. Over the past decade, there have been considerable advances in applying $16 \mathrm{~S}$ rDNA sequencing data to verify associated intestinal bacteria in CRC patients; however, due to variations of individual and environment factors, these results seem to be inconsistent. In this review, we scrutinized the previous $16 \mathrm{~S}$ rDNA sequencing data of intestinal bacteria from CRC patients, and identified twelve genera that are specifically enriched in the tumor microenvironment. We have focused on their relationship with the CRC development, and shown that some bacteria could promote CRC development, acting as foes, while others could inhibit CRC development, serving as friends, for human health. Finally, we highlighted their potential applications for the CRC diagnosis, prevention, and treatment.
\end{abstract}

Keywords: colorectal cancer; intestinal microbiota; colorectal cancer development; tumor microenvironment; $16 \mathrm{~S}$ rDNA sequencing

\section{Introduction}

Colorectal cancer (CRC) is the collective term used for the colon, rectal and anal cancer, and is the second most commonly diagnosed cancer and the third cause of cancer death in the world. It was responsible for over 880,792 deaths and 1,849,518 new cases worldwide in 2018 [1]. As a well-known multi-factorial disease, CRC may stem from different individual genetic background, lifestyle, and environmental factors (such as diet and drugs), and from dynamic imbalance between intestinal microbiota and host immune system [2-8].

Intestinal microbiota is a community of microbes that live in human intestine [9]. It has been considered as an "invisible organ" of human body [10], and contains at least 150 times more genes in total than the host genome [11]. As an "invisible organ", intestinal microbiota or their metabolites can, in fact, significantly impact human health, causing diseases such as obesity [12], diabetes [13], fatty liver disease [14], hypertension and cardiovascular disease [15], CRC [16], etc.

The composition and diversity of intestinal microbiota are influenced by both individual factors, such as age, sex, race, immune system, and environmental factors, including dietary habits and medication usage [17]. More than 1000 microbial species colonize the human intestine [18], with bacteria accounting for about $95 \%$ of the microbe population [18]. The dominant bacterial phyla in healthy 
individuals are Firmicutes, Bacteroidetes, and Actinobacteria, with Proteobacteria and Verrucomicrobia also existing in lower numbers [17]. However, in CRC patients, intestinal bacteria appear to show different profiles. In fact, there is abundant evidence to demonstrate that the composition of intestinal bacteria can potentially contribute to cancer development [7,19-22], and some intestinal bacteria involved in colorectal carcinogenesis can be described by a "driver-passenger" model [23]. The "driver" bacteria are those causing DNA damage in intestinal epithelial cell thus contributing to the initiation of CRC and formation of a tumor microenvironment that comprises cancer cells, normal cells, and the extracellular matrix they secrete [23]. These bacteria include Bacteroides fragili [24], Escherichia coli [24] and Campylobacter jejuni [25], which can secrete B. fragilis toxin (BFT), colibactin, and cytolethal distending toxin (CDT), respectively, to attack intestinal epithelial cells and cause DNA damage. The "passenger" bacteria, on the other hand, are those that are more adapted to the tumor microenvironment, occupying the niche and being able to replace the "driver" bacteria, with most of them either promoting or inhibiting the CRC development [23]. For example, Fusobacterium nucleatum can activate the Wnt/ $\beta$-catenin pathway, stimulate cancer cell growth, and promote CRC development [26]; however, Akkermansia muciniphila can instead enhance the efficacy of programmed death 1 (PD-1) based immunotherapy against CRC [27]. Therefore, identifying bacteria enriched in the tumor microenvironment are important for treatment of CRC. Despite extensive research on intestinal bacteria in patients with CRC, still a large number of CRC-associated bacteria have not yet been identified. Due to the distinct individual and environment factors, these studies on CRC-associated bacteria sometimes suffer from inconsistent results. Thus, a systematic analysis of CRC-associated bacteria is required.

In this review, via analyzing and scrutinizing the abundant $16 \mathrm{~S}$ ribosomal DNA (rDNA) sequencing studies of intestinal bacteria in CRC patients, we conclude that twelve genera were significantly enriched in the CRC patients or tissues. We then discuss these twelve genera in detail, including their roles in the CRC development, the mechanisms for their enrichment in tumor microenvironment of CRC patients, and their application values in the CRC treatment. Our aim is to highlight new ideas for diagnosis (such as validating bacterial biomarkers), prevention, and treatment (via inhibiting carcinogenic bacteria and supplementing probiotics) of CRC.

\section{Bacteria Correlated with CRC}

We have collected and analyzed all reliable $16 \mathrm{~S}$ rDNA sequencing studies of intestinal microbiota from CRC patients (till January 2020), but excluded those of smaller sample sizes ( $<6$ for each group) or non-original studies. Finally, we selected 21 studies for statistical analysis on the bacterial variations in CRC patients (Table 1). We found that the abundance of 32 genera belonging to the Bacteroidetes, Fusobacteria, Verrucomicrobia, Proteobacteria, Firmicutes, and Actinobacteria phyla varied a lot (Table 2). Among them, twelve genera belong to the Bacteroidetes, Fusobacteria, Verrucomicrobia, Proteobacteria, and Firmicutes phyla are significantly enriched in the CRC patients or tissues (Table 3). Thus, we focused on the current progresses of these twelve genera in-depth below.

Table 1. Source of data for this review.

\begin{tabular}{cccccc}
\hline Area & $\begin{array}{c}\text { Group } \\
\text { /Number }\end{array}$ & $\begin{array}{c}\text { 16S rDNA } \\
\text { Region }\end{array}$ & $\begin{array}{c}\text { Group } \\
\text { /Specimens } \\
\text { Type }\end{array}$ & $\begin{array}{c}\text { Intestinal Microbiota Alter in } \\
\text { Tumor Microenvironment of } \\
\text { CRC Patients }\end{array}$ & Ref. \\
\hline China & $\begin{array}{c}\mathrm{CRC} / 9 ; \\
\text { Control/14 }\end{array}$ & $\mathrm{V} 6$ & $\begin{array}{c}\mathrm{CRC} / \mathrm{T} \\
\mathrm{Control} / \mathrm{T}\end{array}$ & $\begin{array}{c}\text { Devosia } \uparrow \\
\text { Eubacterium } \downarrow \\
\text { Right-side tumors: } \\
\text { Fusobacterium } \uparrow \\
\text { Bacteroides fragilis } \uparrow \\
\text { Left-side tumors: } \\
\text { Parvimonas micra } \uparrow \\
\text { Fusobacterium } \uparrow \\
\text { Dermabacter } \uparrow \\
\text { Mucispirillum } \downarrow\end{array}$ & {$[28]$} \\
China & $\mathrm{CRC} / 58$ & $\mathrm{~V} 3-\mathrm{V} 4$ & $\begin{array}{c}\mathrm{CRC} / \mathrm{Pt} \\
\mathrm{Control} / \mathrm{T}\end{array}$ & 29] & [30] \\
\hline
\end{tabular}


Table 1. Cont.

\begin{tabular}{|c|c|c|c|c|c|}
\hline Area & $\begin{array}{l}\text { Group } \\
\text { /Number }\end{array}$ & $\begin{array}{l}\text { 16S rDNA } \\
\text { Region }\end{array}$ & $\begin{array}{c}\text { Group } \\
\text { /Specimens } \\
\text { Type }\end{array}$ & $\begin{array}{c}\text { Intestinal Microbiota Alter in } \\
\text { Tumor Microenvironment of CRC } \\
\text { Patients }\end{array}$ & Ref. \\
\hline Brazil & $\begin{array}{l}\text { CRC/18 } \\
\text { Control/18 }\end{array}$ & V4-V5 & $\begin{array}{c}\mathrm{CRC} / \mathrm{T} \\
\text { Control/T }\end{array}$ & $\begin{array}{c}\text { Parcubacteria } \uparrow \\
\text { Planctomycetes } \downarrow \\
\text { Fusobacterium } \uparrow\end{array}$ & [31] \\
\hline Morocco & $\begin{array}{c}\text { CRC/11 } \\
\text { Control/12 }\end{array}$ & V1-V2 & $\begin{array}{c}\mathrm{CRC} / \mathrm{S} \\
\text { Control/S }\end{array}$ & $\begin{array}{c}\text { Clostridia } \uparrow \\
\text { Bacteroidia } \downarrow \\
\text { Slackia } \downarrow \\
\text { Bacteroidetes Cluster } 2 \uparrow\end{array}$ & [32] \\
\hline Ireland & $\begin{array}{l}\text { CRC/59 } \\
\text { Control/56 } \\
\text { Polyps/21 }\end{array}$ & V3-V4 & $\begin{array}{l}\text { CRC/Pt, S; } \\
\text { Control/T, S; } \\
\text { Polyps/T, S. }\end{array}$ & $\begin{array}{c}\text { Firmicutes Cluster } 2 \uparrow \\
\text { Pathogen Cluster } \uparrow \\
\text { Prevotella Cluster } \uparrow \\
\text { Bacteroidetes Cluster } 1 \downarrow \\
\text { Firmicutes Cluster } 1 \downarrow\end{array}$ & [33] \\
\hline USA & $\begin{array}{c}\text { CRC/74 } \\
\text { Control/94 }\end{array}$ & V3-V4 & $\begin{array}{c}\mathrm{CRC} / \mathrm{S} \\
\text { Control/S }\end{array}$ & $\begin{array}{c}\text { Fusobacterium } \uparrow \\
\text { Porphyromonas } \uparrow \\
\text { Clostridia } \downarrow\end{array}$ & [3] \\
\hline USA & $\begin{array}{l}\text { CRC/10 } \\
\text { Control/11 }\end{array}$ & V4 & $\begin{array}{c}\text { CRC/S } \\
\text { Control/S }\end{array}$ & $\begin{array}{c}\text { Akkermansia muciniphila } \uparrow \\
\text { Citrobacter farmeri } \uparrow \\
\text { Butyrate-producing species } \downarrow \\
\text { Bacteroides fragilis } \uparrow \\
\text { Entcrentocisus } \uparrow\end{array}$ & [34] \\
\hline China & $\begin{array}{l}\text { CRC/46 } \\
\text { Control/56 }\end{array}$ & V3 & $\begin{array}{c}\text { CRC/S } \\
\text { Control/S }\end{array}$ & $\begin{array}{c}\text { Bacteroides vulgatus } \downarrow \\
\text { Bacteroides uniformis } \downarrow \\
\text { Roseburia } \downarrow \\
\text { Butyrate-producing bacteria } \downarrow \\
\text { Lactococcus } \uparrow\end{array}$ & [35] \\
\hline China & $\begin{array}{c}\text { CRC/31 } \\
\text { Control/30 }\end{array}$ & V3 & $\begin{array}{l}\mathrm{CRC} / \mathrm{Pt} \\
\text { Control/ T }\end{array}$ & $\begin{array}{c}\text { Fusobacterium } \uparrow \\
\text { Pseudomonas } \downarrow \\
\text { Escherichia-Shigella } \downarrow \\
\text { Eikenella } \uparrow\end{array}$ & [36] \\
\hline $\begin{array}{l}\text { USA; } \\
\text { Spain }\end{array}$ & CRC/90 & V1-V2 & $\mathrm{CRC} / \mathrm{Pt}$ & $\begin{array}{c}\text { Fusobacterium } \uparrow \\
\text { Bulleida } \uparrow \\
\text { Gemella } \uparrow \\
\text { Parvimonas } \uparrow \\
\text { Campylobacter } \uparrow \\
\text { Streptococcus } \uparrow \\
\text { Porphyromonadaceae } \uparrow\end{array}$ & [37] \\
\hline China & $\begin{array}{c}\text { CRC/19 } \\
\text { Control/20 }\end{array}$ & V3 & $\begin{array}{c}\text { CRC/S } \\
\text { Control/S }\end{array}$ & $\begin{array}{c}\text { Fusobacteriaceae } \uparrow \\
\text { Eubacteriaceae } \uparrow \\
\text { Staphylococcaceae } \uparrow \\
\text { Campylobacteraceae } \uparrow\end{array}$ & [38] \\
\hline China & $\mathrm{CRC} / 8$ & V1-V2 & $\mathrm{CRC} / \mathrm{Pt}$ & $\begin{array}{c}\text { Roseburia } \uparrow \\
\text { Microbacterium } \downarrow \\
\text { Anoxybacillus } \downarrow \\
\text { Ruminococcus } \uparrow\end{array}$ & [39] \\
\hline USA & $\begin{array}{c}\text { CRC/22 } \\
\text { Control/13 }\end{array}$ & $\begin{array}{l}\text { V2-V4; } \\
\text { V6-V9 }\end{array}$ & $\begin{array}{c}\mathrm{CRC} / \mathrm{S} \\
\text { Control/S }\end{array}$ & $\begin{array}{c}\text { Subdoligranulum } \uparrow \\
\text { Bifidobacteriaceae } \downarrow \\
\text { Lactobacillaceae } \downarrow \\
\text { Lachnoclostridium } \downarrow \\
\text { Oscillibacter } \downarrow\end{array}$ & [40] \\
\hline France & $\begin{array}{c}\text { CRC/60 } \\
\text { Control/119 }\end{array}$ & V3-V4 & $\begin{array}{c}\text { CRC/S } \\
\text { Control/S }\end{array}$ & $\begin{array}{c}\text { All bacteria are similar in CRC } \\
\text { and Control, respectively. } \\
\text { Lactobacillales } \uparrow \\
\text { Fusobacterium } \uparrow \\
\text { Porphyromonas } \uparrow\end{array}$ & [41] \\
\hline China & $\begin{array}{c}\mathrm{CRC} / 46 \\
\text { Control/56 }\end{array}$ & V1-V3 & $\begin{array}{l}\text { CRC/S, Pt, M } \\
\text { Control/S, M }\end{array}$ & $\begin{array}{c}\text { Peptostreptococcus } \uparrow \\
\text { Mogibacterium } \uparrow \\
\text { Faecalibacterium } \downarrow \\
\text { Bifidobacterium } \downarrow \\
\text { Blautia } \downarrow\end{array}$ & [42] \\
\hline
\end{tabular}


Table 1. Cont.

\begin{tabular}{|c|c|c|c|c|c|}
\hline Area & $\begin{array}{l}\text { Group } \\
\text { /Number }\end{array}$ & $\begin{array}{l}\text { 16S rDNA } \\
\text { Region }\end{array}$ & $\begin{array}{c}\text { Group } \\
\text { /Specimens } \\
\text { Type }\end{array}$ & $\begin{array}{c}\text { Intestinal Microbiota Alter in } \\
\text { Tumor Microenvironment of } \\
\text { CRC Patients }\end{array}$ & Ref. \\
\hline USA & CRC/95 & V3-V5 & $\mathrm{CRC} / \mathrm{Pt}$ & Fusobacterium $\uparrow$ & [43] \\
\hline Brazil & $\mathrm{CRC} / 15$ & V4 & $\mathrm{CRC} / \mathrm{Pt}$ & Fusobacterium nucleatum $\uparrow$ & [44] \\
\hline China & $\begin{array}{l}\text { CRC/50; } \\
\text { Control/50 }\end{array}$ & $\mathrm{V} 3-\mathrm{V} 4$ & $\begin{array}{l}\text { CRC/S } \\
\text { Control/S }\end{array}$ & $\begin{array}{c}\text { Gammaproteobacteria } \uparrow \\
\text { Enterobacteriaceae } \uparrow \\
\text { Fusobacteriales } \uparrow\end{array}$ & [45] \\
\hline China & $\begin{array}{c}\mathrm{CRC} / 52 \\
\text { CRA/47 } \\
\text { Control/61 }\end{array}$ & $\begin{array}{c}\text { Not } \\
\text { mention }\end{array}$ & $\begin{array}{c}\text { CRC/M } \\
\text { CRA/M } \\
\text { Control/M }\end{array}$ & $\begin{array}{c}\text { Bacteroides fragilis } \uparrow \\
\text { Fusobacterium } \uparrow\end{array}$ & [46] \\
\hline China & $\begin{array}{c}\text { CRC/8 } \\
\text { CRA/10 } \\
\text { Control/10 }\end{array}$ & V1-V2 & $\begin{array}{c}\mathrm{CRC} / \mathrm{T} \\
\mathrm{CRA} / \mathrm{T} \\
\text { Control/T }\end{array}$ & $\begin{array}{l}\text { The driver bacterial cluster is } \\
\text { significantly and positively } \\
\text { correlated to the } \\
\text { pro-inflammatory passenger } \\
\text { bacterial cluster }\end{array}$ & [47] \\
\hline
\end{tabular}

CRC: Colorectal cancer; CRA: Colorectal adenoma; T: Tissue; Pt: Paired tissue (CRC tissues and adjacent non-cancer tissues); S: Stool; M: Mucosa; Upward arrows indicate increase of bacterial number; Down arrows indicate decrease of bacterial number.

Table 2. Altered bacterial populations in CRC patients compared to healthy individuals, and in CRC tissues compared to adjacent non-cancer tissues.

\begin{tabular}{|c|c|c|c|c|}
\hline \multirow{2}{*}{ Bacteria } & \multicolumn{2}{|c|}{ CRC Patients vs. Healthy Individuals } & \multicolumn{2}{|c|}{$\begin{array}{l}\text { CRC Tissues vs. } \\
\text { Adjacent Non-Cancer Tissues }\end{array}$} \\
\hline & Ref. ( $\uparrow$ in CRC) & Ref. ( $\downarrow$ in CRC) & Ref. ( $\uparrow$ in CRC) & Ref. ( $\downarrow$ in CRC) \\
\hline Porphyromonas & {$[32,33,35,42,45,47]$} & - & [30] & - \\
\hline Parabacteroides & {$[31,32]$} & - & - & {$[30,37,42]$} \\
\hline Bacteroides & [31] & {$[34,35]$} & {$[36]$} & [44] \\
\hline Prevotella & [33] & {$[28,34]$} & {$[30,36]$} & [44] \\
\hline Paraprevotella & {$[42]$} & - & - & {$[42,44]$} \\
\hline Butyricimonas & {$[31,32]$} & - & {$[37]$} & - \\
\hline Akkermansia & {$[32,34,37]$} & - & - & - \\
\hline Campylobacter & {$[33,38,46]$} & - & {$[37,44]$} & - \\
\hline Desulfovibrio & {$[31,42,46]$} & - & - & - \\
\hline Sphingomonas & - & {$[31,36,46]$} & - & - \\
\hline $\begin{array}{l}\text { Escherichial } \\
\text { Shigella }\end{array}$ & {$[33,35,36,45]$} & [31] & - & - \\
\hline Klebsiella & [42] & {$[28,31,33]$} & - & - \\
\hline Acinetobacter & - & {$[31,36]$} & - & [30] \\
\hline Pseudomonas & - & {$[31,36]$} & - & {$[30,36,44]$} \\
\hline Fusobacterium & {$[32,33,36,38,42,45,46]$} & - & {$[30,36,37,43,44]$} & - \\
\hline Leptotrichia & {$[46]$} & [28] & - & [28] \\
\hline Blautia & - & {$[33,42,46]$} & - & - \\
\hline Roseburia & [31] & [35] & [39] & - \\
\hline Lachnospira & [31] & [42] & - & [37] \\
\hline Anaerostipes & [31] & {$[33,42]$} & - & - \\
\hline Streptococcus & {$[33,35,46,47]$} & - & [36] & - \\
\hline Lactococcus & [36] & - & [36] & {$[30]$} \\
\hline Bacillus & - & [31] & - & {$[30,42]$} \\
\hline Clostridium & {$[31,32,46]$} & - & {$[44]$} & - \\
\hline Eubacterium & {$[33,42]$} & {$[28,35]$} & [33] & - \\
\hline Parvimonas & {$[33,45,46]$} & - & {$[30,44]$} & - \\
\hline Peptostreptococcus & {$[32,33,35,36,42,46]$} & - & {$[30,44]$} & - \\
\hline Mogibacterium & {$[33,42,46]$} & [28] & - & - \\
\hline Phascolarctobacterium & {$[31,33]$} & [28] & - & [42] \\
\hline Oscillospira & {$[31,32,46]$} & - & - & - \\
\hline Ruminococcus & {$[31-33,40]$} & - & [44] & - \\
\hline Faecalibacterium & - & {$[33,42,45,46]$} & - & - \\
\hline
\end{tabular}




\subsection{Bacteria Correlated with CRC in Bacteroidetes Phylum}

\subsubsection{Bacteroides}

Bacteroides is a Gram-negative, anaerobic, non-motile, and rod-shaped bacterium, with most of them containing no flagellum (Table 3). It normally resides in the oral cavity, upper respiratory tract, intestine and reproductive tract of human. Thomas et al. found that Bacteroides is abundant in the intestines of CRC patients compared to the healthy individuals [31], yet some studies found that Bacteroides is depleted in the intestines of CRC patients compared to the healthy individuals [34,35]. Gao et al. also reported that Bacteroides is abundant in CRC tissues compared to adjacent non-cancer tissues [36]; however, Carvalho et al. demonstrated that Bacteroides are depleted in CRC tissues compared to adjacent non-cancer tissues (Table 2) [44]. These differences may be due to the different species of Bacteroides existing in the intestines of CRC patients. For examples, B. finegoldii, B. intestinalis, and B. capillosus are significantly enriched in healthy individuals compared to the CRC patients [34], while $B$. fragilis is enriched in the intestines of CRC patients compared to healthy individuals [35].

Table 3. Basic characteristics of twelve genera of bacteria.

\begin{tabular}{|c|c|c|c|}
\hline Taxonomy * & Genera & Characteristics & Relationship with CRC \\
\hline $\begin{array}{l}\text { Bacteroidetes } \\
\text { Bacteroidia } \\
\text { Bacteroidales } \\
\text { Bacteroidaceae }\end{array}$ & Bacteroides & $\begin{array}{l}\text { Gram-negative, } \\
\text { anaerobic, } \\
\text { non-motile, } \\
\text { rod-shaped. }\end{array}$ & $\begin{array}{l}\text { ETBF secretes BFT to promote CRC } \\
\text { development }\end{array}$ \\
\hline $\begin{array}{l}\text { Bacteroidetes } \\
\text { Bacteroidia } \\
\text { Bacteroidales } \\
\text { Porphyromonadaceae }\end{array}$ & Porphyromonas & $\begin{array}{l}\text { Gram-negative, } \\
\text { anaerobic, } \\
\text { non-motile, } \\
\text { rod-shaped. }\end{array}$ & $\begin{array}{l}\text { Porphyromonas can activate } \\
\text { inflammatory responses, may } \\
\text { accelerate CRC development. }\end{array}$ \\
\hline $\begin{array}{l}\text { Fusobacteria; } \\
\text { Fusobacteriia } \\
\text { Fusobacteriales } \\
\text { Fusobacteriaceae }\end{array}$ & Fusobacterium & $\begin{array}{l}\text { Gram-negative, } \\
\text { obligate anaerobic, } \\
\text { non-motile, } \\
\text { spindle-shaped. }\end{array}$ & $\begin{array}{l}\text { Fusobacterium destroys the intestinal } \\
\text { barrier, activates Wnt/ } \beta \text {-catenin } \\
\text { pathway, and promotes CRC } \\
\text { development. }\end{array}$ \\
\hline $\begin{array}{l}\text { Fusobacteria } \\
\text { Fusobacteriia } \\
\text { Fusobacteriales } \\
\text { Leptotrichiaceae }\end{array}$ & Leptotrichia & $\begin{array}{l}\text { Gram-negative, } \\
\text { anaerobic, } \\
\text { non-motile, } \\
\text { straight or slightly curved. }\end{array}$ & $\begin{array}{l}\text { It is still unclear and needs further } \\
\text { research. }\end{array}$ \\
\hline $\begin{array}{l}\text { Verrucomicrobia } \\
\text { Verrucomicrobiae } \\
\text { Verrucomicrobiales } \\
\text { Akkermansiaceae }\end{array}$ & Akkermansia & $\begin{array}{l}\text { Gram-negative, } \\
\text { obligate anaerobic, } \\
\text { non-motile, } \\
\text { elliptical-shaped. }\end{array}$ & $\begin{array}{l}\text { Akkermansia influences efficacy of } \\
\text { PD-1-based immunotherapy against } \\
\text { CRC }\end{array}$ \\
\hline $\begin{array}{l}\text { Proteobacteria } \\
\text { Epsilonproteobacteria } \\
\text { Campylobacterales } \\
\text { Campylobacteraceae }\end{array}$ & Campylobacter & $\begin{array}{l}\text { Gram-negative, } \\
\text { aerobic or anaerobic, } \\
\text { motile, } \\
\text { curved-shaped. }\end{array}$ & $\begin{array}{l}\text { C. jejuni can promote CRC } \\
\text { development through the action of } \\
\text { CDT }\end{array}$ \\
\hline $\begin{array}{l}\text { Proteobacteria } \\
\text { Deltaproteobacteria } \\
\text { Desulfovibrionales } \\
\text { Desulfovibrionaceae }\end{array}$ & Desulfovibrio & $\begin{array}{l}\text { Gram-negative, } \\
\text { obligate anaerobic, } \\
\text { motile, } \\
\text { curved- or spiral rod- shaped. }\end{array}$ & $\begin{array}{l}\text { Desulfovibrio produces hydrogen } \\
\text { sulphide, which can promote } \\
\text { oxidation and DNA damage to } \\
\text { promote CRC development }\end{array}$ \\
\hline $\begin{array}{l}\text { Proteobacteria } \\
\text { Gammaproteobacteria } \\
\text { Enterobacterales } \\
\text { Enterobacteriaceae }\end{array}$ & Escherichia/Shigella & $\begin{array}{l}\text { Gram-negative, } \\
\text { facultative anaerobic, } \\
\text { non-motile, } \\
\text { rod-shaped. }\end{array}$ & $\begin{array}{l}p k s^{+} \text {E. coli secretes toxins, which can } \\
\text { attack host DNA directly, increase } \\
\text { mutation frequency and risk of CRC }\end{array}$ \\
\hline $\begin{array}{l}\text { Firmicutes } \\
\text { Bacilli } \\
\quad \text { Lactobacillales } \\
\quad \text { Streptococcaceae }\end{array}$ & Streptococcus & $\begin{array}{l}\text { Gram-positive, } \\
\text { Facultative anaerobic/obligate, } \\
\text { anaerobic, } \\
\text { non-motile, } \\
\text { round- or ovoid- shaped. }\end{array}$ & $\begin{array}{l}\text { S. gallolyticus aggravates the tumor } \\
\text { microenvironment thereby } \\
\text { accelerating CRC development }\end{array}$ \\
\hline
\end{tabular}


Table 3. Cont.

\begin{tabular}{|c|c|c|c|}
\hline Taxonomy * & Genera & Characteristics & Relationship with CRC \\
\hline $\begin{array}{l}\text { Firmicutes } \\
\text { Clostridia } \\
\text { Clostridiales } \\
\text { Clostridiaceae }\end{array}$ & Clostridium & $\begin{array}{l}\text { Gram-positive, } \\
\text { anaerobic, } \\
\text { motile, } \\
\text { rod-shaped. }\end{array}$ & $\begin{array}{l}\text { C. difficile can secrete toxins, increase } \\
\text { permeability of intestinal barrier, } \\
\text { and promote CRC development } \\
\text { C. butyricum can relieve intestinal } \\
\text { inflammation, improve immune } \\
\text { homeostasis, and inhibit CRC } \\
\text { development }\end{array}$ \\
\hline $\begin{array}{l}\text { Firmicutes } \\
\text { Tissierellia } \\
\text { Tissierellales } \\
\text { Peptoniphilaceae }\end{array}$ & Parvimonas & $\begin{array}{l}\text { Gram-positive, } \\
\text { obligate anaerobic, } \\
\text { non-motile, } \\
\text { round-shaped. }\end{array}$ & $\begin{array}{l}\text { It is still unclear and needs further } \\
\text { research. }\end{array}$ \\
\hline $\begin{array}{l}\text { Firmicutes } \\
\text { Clostridia } \\
\text { Clostridiales } \\
\text { Peptostreptococcaceae }\end{array}$ & Peptostreptococcus & $\begin{array}{l}\text { Gram-positive, } \\
\text { obligate anaerobic, } \\
\text { nonmotile, } \\
\text { round- or oval- shaped. }\end{array}$ & $\begin{array}{l}\text { P. anaerobius can activate NF- } \mathrm{KB} \text { and } \\
\text { enhance cell proliferation, } \\
\text { subsequently accelerates } \mathrm{CRC} \\
\text { development }\end{array}$ \\
\hline
\end{tabular}

In the Bacteroides genus, there is a conserved and unique genetic locus encoding polysaccharide utilization protein named commensal colonization factor (CCF) (Table 4). The expression of $c c f$ is up-regulated during the colonization of Bacteroides, which contributes to the passage of $B$. fragilis via the colonic mucus to reside in the crypt [48]. CCF-mediated colonization of B. fragilis in the intestine usually requires immunoglobulin $\mathrm{A}(\mathrm{IgA})$, and CCF can regulate the level of specific capsular polysaccharides to bind IgA and thus promote B. fragilis colonization [49]. In addition, metalloproteinase 2 produced by $B$. fragilis can bind with the E-cadherin of host intestinal epithelial cells [50] (Table 4), suggesting that metalloproteinase 2 may contribute to colonization of $B$. fragilis in the intestine too.

Table 4. Mechanisms for bacterial colonization in the intestine.

\begin{tabular}{|c|c|c|c|}
\hline Bacteria & Colonization Factor & Host Colonization Target & Ref. \\
\hline \multirow{2}{*}{ B. fragilis } & $c c f$ & $\operatorname{Ig} \mathrm{A}$ & {$[48,49]$} \\
\hline & Metalloproteinase 2 & E-cadherin & [50] \\
\hline \multirow{2}{*}{ F. nucleatum } & Fap2 & Gal-GalNAc, overexpressed in CRC cells & [51] \\
\hline & FadA & E-cadherin & [26] \\
\hline \multirow[t]{2}{*}{ A. muciniphila } & Substrate mucin & $\begin{array}{l}\text { MUC1, increased in colon cancer } \\
\text { MUC5AC, absent from normal colon }\end{array}$ & [52] \\
\hline & CadF & Fibronectin & [53] \\
\hline \multirow{3}{*}{ C. jejuni } & FlpA & Fibronectin & [54] \\
\hline & PEB1 & - & [55] \\
\hline & FliD & Heparan sulfate glycosaminoglycan receptors & [56] \\
\hline \multirow{2}{*}{ E. coli } & Intimin & 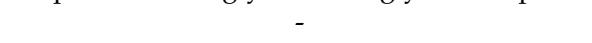 & [57] \\
\hline & Afa-1 & - & [58] \\
\hline S. gallolyticus & - & $\begin{array}{l}\text { Collagen I, increased in serum and tissues of } \\
\text { CRC patients } \\
\text { Collagen IV, highly expressed in desmoplasia } \\
\text { of CRC liver metastases patients }\end{array}$ & [59-61] \\
\hline \multirow{4}{*}{ C. difficile } & SlpA & - & [62] \\
\hline & Cwp66 & - & [63] \\
\hline & Fbp68 & Fibronectin & [64] \\
\hline & CbpA & $\begin{array}{l}\text { Collagens I, increased in serum and tissues of } \\
\text { CRC patients } \\
\text { Collagens V }\end{array}$ & {$[64]$} \\
\hline P. anaerobius & PCWBR2 & $\alpha 2 / \beta 1$ Integrin, overexpressed in CRC tissues & [65] \\
\hline
\end{tabular}

BFT secreted by enterotoxigenic $B$. fragilis (ETBF), is a $20 \mathrm{kDa}$ zinc-dependent metalloprotease toxin. It can cleave E-cadherin, reduce colonic barrier, and promote intestinal inflammation (Figure 1a) [66]. Besides, bft gene is more common in the intestinal mucosa of CRC patients, especially those at the terminal stage [67]. BFT can also stimulate interleukin 17 (IL-17) and IL-23 production, and mucosal immune response in the colonic epithelium, as well as promote the proliferation and metabolism of 
colonic epithelial cells. It can also recruit tumor-promoting myeloid cells to infiltrate and exacerbate terminal stage tumor formation [68], and activate the mitogen-activated protein kinase (MAPK) signaling, thereby promoting uncontrolled proliferation of epithelial cells (Figure 1a) [69]. Besides, ETBF can also induce spermine oxidase (SPO) to generate abundant reactive oxygen species (ROS), thereby causing DNA damage (Figure 1a) [70]. Since not all $B$. fragile can produce the toxins that accelerate CRC development, designing anti- BFT drugs may be more effective than anti-B. fragile bactericides for treating CRC. Meanwhile, BFT may serve as a promising biomarker for the diagnosis of CRC.

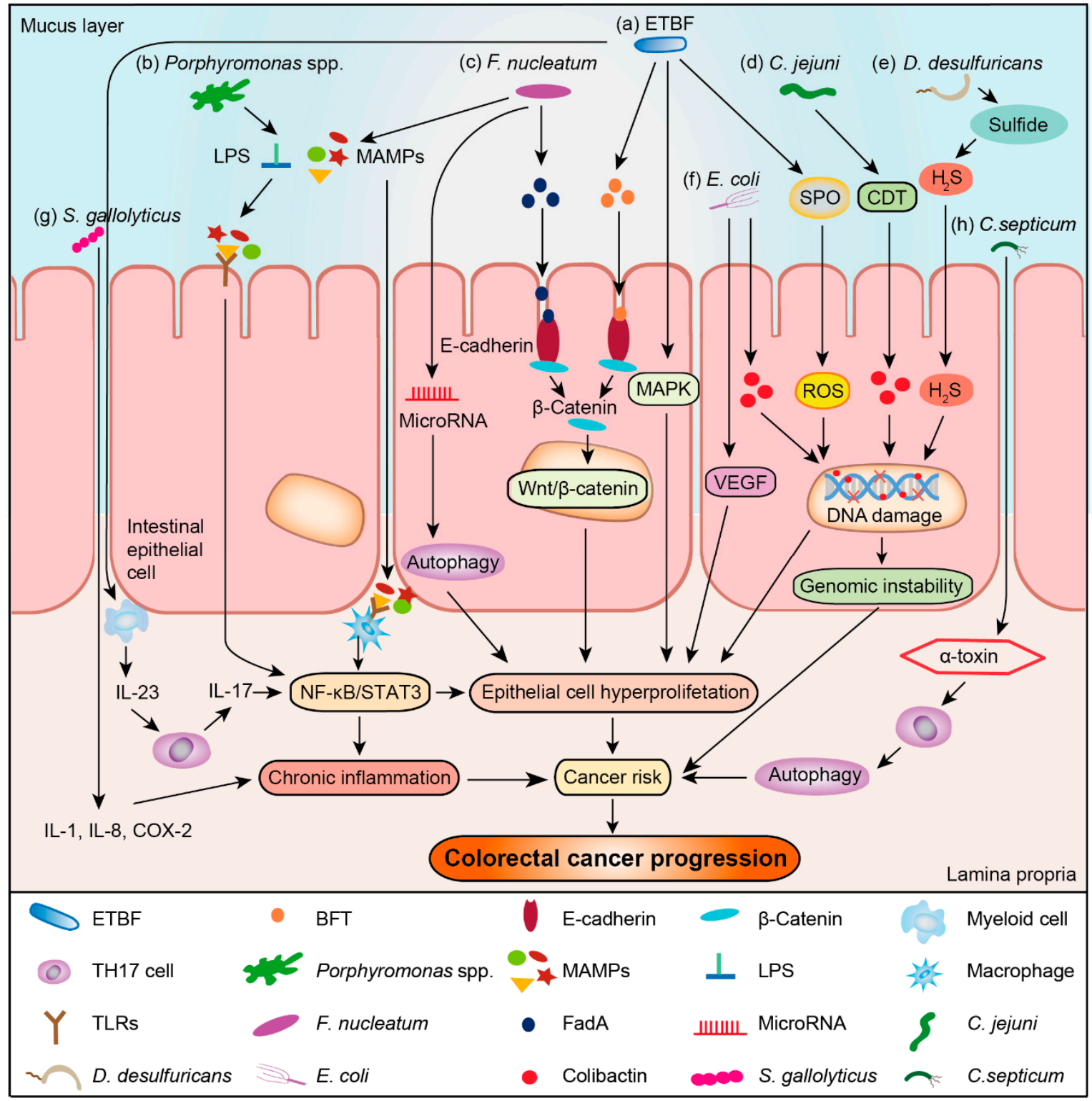

Figure 1. Bacteria-associated mechanisms involved in the development and progression of CRC. (a) Enterotoxigenic B. fragilis (ETBF) secretes B. fragilis toxin (BFT) to interact with the E-cadherin and $\beta$-catenin of host cells at adherent junctions, activate the $\mathrm{Wnt} / \beta$-catenin signal pathway, and drive the transcription of genes related to apoptosis, cell proliferation, or transformation. Meanwhile, BFT can activate the mitogen-activated protein kinase (MAPK) signaling pathway to enhance uncontrolled proliferation of epithelial cells. Furthermore, ETBF stimulates IL-17 and IL-23 production, and induces mucosal immune response in the colonic epithelium to promote the proliferation and metabolism of colonic epithelial cells through the nuclear factor- $\mathrm{kB}(\mathrm{NF}-\mathrm{kB})$ / signal transducer and activator of transcription 3 (STAT3) pathway. Besides, ETBF also induces spermine oxidase (SPO) to generate reactive 
oxygen species (ROS), thereby inducing DNA damage; (b) Recognition of microbe-associated molecular patterns (MAMPs), such as lipopolysaccharide (LPS) of Porphyromonas spp. can activate macrophages via binding its Toll-like receptors (TLRs) to activate the STAT3 or NF- $\mathrm{KB}$ pathway to transmit signals to the nucleus for regulating cellular growth, apoptosis, angiogenesis, migration, and cellular invasion; (c) Fusobacterium adhesin A (FadA) of F. nucleatum can bind E-cadherin of intestinal epithelial cells to activate $\beta$-catenin, leading to uncontrolled cell growth and acquisition of a stem cell-like phenotype. Furthermore, F. nucleatum is shown to modulate autophagy of intestinal epithelial cells by activating regulatory microRNAs. F. nucleatum also contributes to proinflammatory effects via recognition of MAMPs by TLRs, leading to the activation of the NF-kB or STAT3 pathway and accelerating CRC development; (d) C. jejuni can promote colorectal carcinogenesis through the production of cyto-lethal distending toxin (CDT), which then induces the DNA double-strand breaks, resulting in mutagenesis and chromosomal instability; these processes are also involved in cancer initiation and development; (e) D. desulfuricans can reduce sulphur or sulphur-containing compounds to hydrogen sulphide $\left(\mathrm{H}_{2} \mathrm{~S}\right)$, which can promote oxidation and DNA damage to promote cancer development when hydrogen sulphide is present in high concentrations; (f) E. coli strains harboring the $p k s$ island for encoding polyketide synthases can produce genotoxin colibactin to induce DNA double-strand breaks, resulting in cancer initiation and development. E. coli can also promote vascular endothelial cell migration and increase vascular permeability by increasing the production of vascular endothelial growth factor (VEGF). All of these effects are necessary for tumor vascularization, proliferation, and migration; (g) S. gallolyticus can promote the production of inflammatory factors such as IL-1, IL-8, and cyclooxygenase-2 (COX-2), thereby accelerating CRC development through chronic inflammation; (h) C. septicum can produce $\alpha$-toxin to induce apoptosis in neutrophils in the tumor microenvironment, thereby downregulating tumor immune response and accelerating CRC development.

\subsubsection{Porphyromonas}

Porphyromonas is a Gram-negative, anaerobic, non-motile and rod-shaped bacterium (Table 3). It is frequently present in the human oral cavity. The abundance of Porphyromonas in the intestines of CRC patients is higher than that of healthy individuals. Further, Porphyromonas is more abundant in CRC tissues compared to adjacent non-cancer tissues (Table 2) [32,33,35,42,45,47]. However, how Porphyromonas is enriched in this tumor microenvironment remains unclear.

Porphyromonas has been found to activate host inflammatory responses in many studies [71,72]. As shown in Figure 1b, P. gulae can first activate unprimed macrophages via Toll-like receptors 2 (TLR2) and Toll-like receptor 4 (TLR4), followed by inducing the effector functions of M1 macrophages via TLR2 [71]; some microbe-associated molecular patterns (MAMPs), including DNA, flagellin, lipopolysaccharide (LPS) and so on can also activate inflammatory responses, for example, the LPS of $P$. gingivalis can activate M1 and M2 macrophages by TLR2 to secrete inflammatory cytokines, such as tumor necrosis factor $\alpha$ (TNF- $\alpha)$ and IL-4 [72]. Porphyromonas has previously been found to be an oral pathogen, yet its role in the intestine is rarely studied. Thus, more studies are required to verify the relationship between Porphyromonas and CRC development.

\subsection{Bacteria Correlated with CRC in Fusobacteria Phylum}

\subsubsection{Fusobacterium}

Fusobacterium is a Gram-negative, obligate anaerobic, non-motile and spindle-shaped bacterium (Table 3). Fusobacterium inhabits in human oral cavity, gastrointestinal tract, and urogenital tract. The species belong to the Fusobacterium genera are highly heterogeneous. Among them, some have been recognized as opportunistic pathogens involved not only in periodontitis, inflammatory bowel disease, pancreatic abscess, premature, and hepatic abscess but also in CRC and oral cancer [73-75]. Many studies show that Fusobacterium is more abundant in the intestines of CRC patients compared to the healthy individuals $[32,33,36,38,42,45,46]$. Comparation between CRC tissues and adjacent non-cancer 
tissues also reveals that Fusobacterium is more abundant in the CRC tissues (Table 2) $[30,36,37,43,44]$. These studies indicate that there is a close relationship between Fusobacterium and CRC development.

As an oral bacterium, how can Fusobacterium colonize colorectal tissues? Interestingly, adhesion protein Fap2 of F. nucleatum has been found to bind to the D-galactose- $\beta(1-3)-\mathrm{N}$-acetyl-D-galactosamine (Gal-GalNAc), which is over-represented in CRC cells (Figure 2a and Table 4) [51]. Further, Fusobacterium adhesin A (FadA) can help F. nucleatum adhere to E-cadherin of intestinal epithelial cells (Figure 2a and Table 4) [26]. F. nucleatum can thus selectively colonize in CRC tissues with the assistance of Fap2 and FadA. When injected into the tail veins of precancerous and malignant CRC mouse models, F. nucleatum is also found to colonize in the CRC tissues [51], suggesting that F. nucleatum uses a hematogenous route to reach CRC tissues from the oral cavity.

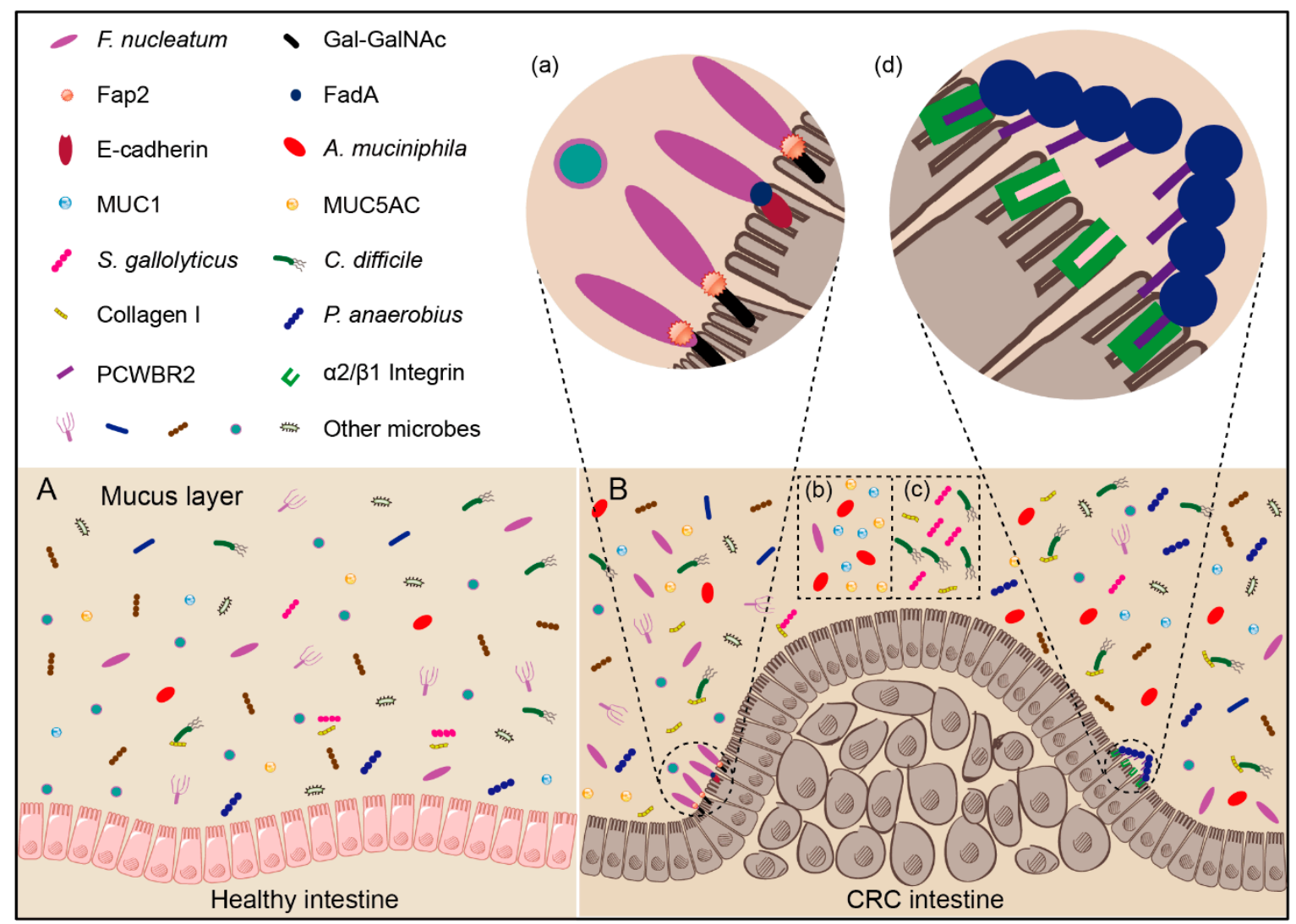

Figure 2. Potential mechanism of bacterial enrichment in CRC tissues. (A) Healthy intestine. (B) CRC intestine: (a) Gal-GalNAc is overexpressed in CRC cells, onto which the Fap2 of F. nucleatum can directly bind, resulting in specific F. nucleatum accumulation in CRC tissues; on the other hand, FadA can help F. nucleatum adhere to E-cadherin of intestinal epithelial cells; (b) MUC1 and MUC5AC are increased in the intestine of colorectal cancer patients. Due to the increasing available substrates, the abundance of A. muciniphila in the intestine of colorectal cancer patients is thus increased; (c) Collagen I is increased in the intestine of colorectal cancer patients. S. gallolyticus and C. difficile can combine with collagens I, resulting in increased abundance in the intestine of colorectal cancer patients; (d) The surface protein PCWBR2 of $P$. anaerobius can directly interact with the colorectal epithelial cell via $\alpha 2 / \beta 1$ integrin, which is frequently overexpressed in CRC tissues.

In the Apc Min/+ mouse model of CRC, F. nucleatum can increase tumor multiplicity, activate nuclear factor kappa-B (NF-кB) pathway, and drive myeloid cell infiltration into tumors to generate a pro-inflammatory environment that promote CRC development (Figure 1c) [20]. There is also a report that F. nucleatum can increase the proliferation of CRC cells and tumor development via TLR4 signaling activation. Indeed, F. nucleatum can target the TLR4 and myeloid differential protein-88 (MyD88) 
innate immune signaling with specific microRNAs to activate the autophagy pathway, leading to different CRC chemotherapeutic response to promote CRC resistance to chemotherapy (Figure 1c) [76]. The virulence factor FadA can promote E-cadherin-mediated tumor growth and induce host to produce proinflammatory cytokines, with the $f a d A$ gene levels in the colon tissues from patients with adenomas and adenocarcinomas being $>10-100$ folds higher than healthy individuals (Figure 1c) [26]. Fap2 protein of $F$. nucleatum can also directly interact with the T-cell immunoreceptor with Ig and ITIM domains (TIGIT) protein, inhibiting of natural killer cell cytotoxicity [77].

These studies indicate that Fusobacterium can not only serve as a CRC biomarker for the diagnosis and prognostic assessment, but also as a potential therapeutic target for CRC.

\subsubsection{Leptotrichia}

Leptotrichia is a Gram-negative, anaerobic, non-motile and straight or slightly curved bacterium (Table 3). It is found mostly in the oral cavity and some other parts of the human body, such as human gastrointestinal tract, periurethral region, and the genitalia of women [78]. The abundance of Leptotrichia is lower in CRC patients compared to healthy individuals [27]. After comparing the CRC tissues with adjacent non-cancer tissues, de Carvalho et al. showed that the abundance of Leptotrichia is decreased in the CRC tissues [44]. However, $\mathrm{Xu}$ and Jiang instead found that Leptotrichia is more abundant in the CRC patients (Table 2) [46]. These different results may be due to: (1) The sample size is insufficient to reach a distinct conclusion; and (2) The right colon cancer and left colon cancer may exhibit some differences. For example, Leptotrichia are more abundant in the left colon cancer patients compared to the right colon cancer patients [79], but this study didn't seem to contain control samples from healthy individuals. More studies are required to verify the relationship between Leptotrichia and CRC development.

\subsection{Bacteria Correlated with CRC in Verrucomicrobia Phylum}

\section{Akkermansia}

Akkermansia is a Gram-negative, obligate anaerobic, non-motile and elliptical-shaped bacterium (Table 3). It is also an intestinal symbiotic bacterium colonizing in the mucosal layer of human intestine. In fact, A. muciniphila can use mucin as its sole sources of carbon, nitrogen, and energy, and is thus considered to be a promising candidate as probiotics. It may keep host-intestinal microbiota balance by converting mucin into beneficial by-products [80]. In fact, clinical studies reveal that the abundance of Akkermansia is generally decreased in individuals with metabolic impairments [81]. To date, no evidence can prove that $A$. muciniphila alone can cause pathogenicity. In fact, A. muciniphila can alleviate a range of diseases, including type I diabetes [82], alcoholic liver [83], progeroid [84], cancer [27], and obesity [85].

Many studies show that $A$. muciniphila has a higher relative abundance in CRC patients compared to healthy individuals (Table 2) $[32,34,37]$. For example, Byrd and Bresalier found that the expression of mucin 1 (MUC1) is increased in colon cancers and that of mucins 5AC (MUC5AC) is frequently present in colorectal adenomas and colon cancers [52] (Table 4), indicating that the enrichment of A. muciniphila in tumor microenvironment may result from the increased substrate concentration (Figure $2 \mathrm{~b}$ ). However, there is no report yet that $A$. muciniphila can promote the development of CRC.

A recent study also revealed that $A$. muciniphila is especially enriched in cancer patients responding to PD-1 treatment compared to non-responders [27]. In mouse models, after treatment of fecal microbiota transplantation (FMT) with non-responders' feces and along with oral supplementation with A. muciniphila, the mouse can restore efficacy of PD-1 blockade [27]. Based on its enrichment in intestines of CRC patients and the probiotic effect, A. muciniphila has thus the potential to serve as an anticancer probiotic. 


\subsection{Bacteria Correlated with CRC in Proteobacteria Phylum}

\subsubsection{Campylobacter}

Campylobacter is a Gram-negative, aerobic or anaerobic, motile and curved-shaped bacterium (Table 3). It is typically found in the human intestine and invades the lining of the human small intestine. Many studies revealed that Campylobacter is enriched in the CRC tissues compared to adjacent non-cancer tissues [37,44]. Meanwhile, the abundance of Campylobacter in the intestines of CRC patients is higher than that of healthy individuals (Table 2) $[33,38,46]$.

The colonization of $C$. jejuni in the intestine is mediated by the binding of Campylobacter adhesin to fibronectin (CadF), fibronectin-like protein (FlpA), and permease PEB1 with their corresponding targets (Table 4). Both CadF and FlpA can bind to fibronectin, which is the main ingredient of the extracellular matrix of intestinal epithelial cells, leading to the colonization of $C$. jejuni in the intestine $[53,54]$. The colonization mechanism mediated by PEB1 is unclear, but the colonization capacity of PEB1-deleted strains is found to reduce by 50-100 folds [55]. In addition, FliD, a terminal cap protein of flagella in C. jejuni, can interact with the heparan sulfate glycosaminoglycan receptors on the intestinal epithelial cell surface [56], thus facilitating the C. jejuni colonization in intestine (Table 4).

Campylobacter is reported to be associated with development of inflammatory bowel disease, which can increase the risk for CRC [86]. Further, C. jejuni can promote CRC development through the action of CDT in Germ-free (GF) $A p c^{\mathrm{Min} /{ }^{+}}$mice (Figure 1d) [87]. In short, C. jejuni can accelerate the development of CRC, but the mechanisms for Campylobacter enrichment in CRC tissues remain unknown. Further researches are needed in this area to reach a conclusion.

\subsubsection{Desulfovibrio}

Desulfovibrio is a Gram-negative, obligate anaerobic, motile and curved- or spiral rod-shaped bacterium (Table 3). It can exist under different habitats, including human intestine. Desulfovibrio is one of the sulphate-reducing bacteria that serve as a terminal oxidant to anaerobically degrade organic matter entering the gastrointestinal tract [88]. Desulfovibrio is more abundant in the intestines of CRC patients than in healthy individuals (Table 2) [31,33,38].

Desulfovibrio can extensively use various substrates, including hydrogen, alcohols, short-chain fatty acids, other organic acids, and amino acids, to reduce sulphur or sulphur-containing compounds to hydrogen sulphide $\left(\mathrm{H}_{2} \mathrm{~S}\right)$ [88]. High concentrations of $\mathrm{H}_{2} \mathrm{~S}$ can inhibit cytochrome $\mathrm{C}$ oxidase (complex IV), subsequently disrupting mitochondrial electron transport. Additionally, $\mathrm{H}_{2} \mathrm{~S}$ can also promote oxidation and DNA damage to promote cancer development (Figure 1e) [89]. These studies may explain the role of Desulfovibrio in cancer development. Besides, the LPS of D. desulfuricans is capable of modulating transcriptional activity of NF- $\kappa \mathrm{B}, \mathrm{p} 65$, and $\mathrm{I} \kappa \mathrm{B} \alpha$ encoding genes in colon cancer cells [90]. Although there is no direct evidence that Desulfovibrio can cause CRC, Desulfovibrio is possibly playing a role in the development of CRC.

\subsubsection{Escherichia/Shigella}

Escherichia/Shigella are Gram-negative, facultative anaerobic and rod-shaped bacteria, with Escherichia being motile while Shigella being non-motile (Table 3). Both can colonize in the human intestines, and are mostly harmless, but certain strains can be very contagious, resulting in painful abdominal cramps, diarrhea, and fever. Escherichia/Shigella show significant different abundance between CRC patients and healthy individuals. Some studies indicate that CRC patients have higher abundance of Escherichia/Shigella [33,35,36,45], whereas other studies instead reveal that those of Escherichia/Shigella are decreased in the rectal cancer patients compared to healthy individuals (Table 2) [31].

Although E. coli normally inhabits in the human intestine. Prorok-Hamon et al. identified an $a f a-1$ operator in the colonic mucosal E. coli, which encodes afimbrial adhesin to adhere and invade intestinal epithelial cells (Table 4) [58]. Meanwhile, they confirmed that Afa-1 can up-regulate VEGF expression 
in epithelial cells, promoting angiogenesis and CRC development (Figure 1f) [58]. In fact, bacterial adhesion protein intimin, which is encoded by the eae gene, can also help E. coli attach closely to the intestinal mucosa [57] (Table 4). In addition, phylogenetic analysis shows that E. coli comprises four main phylogenetic groups (A, B1, B2, and D), and most strains of group A and D are highly adherent to the intestinal epithelial cells; on the other hand, strain of group B2 instead displays low level of adhesion to intestinal epithelial cells [91].

E. coli strains of group B2 also harbor a genomic island called "pks", which encodes a hybrid polyketide-peptide genotoxin of colibactin. Deletion of this pks island from E. coli NC101 is found to cause decreasing tumor multiplicity and invasion in the AOM/IL10 ${ }^{-/}$mice without altering intestinal inflammation [92]. Colibactin toxin can attack host DNA directly, via introducing double-stranded DNA breaks that give rise to genomic instability, leading to increased mutation frequency and risk of CRC (Figure 1f) [93]. In addition, the encoding gene of colibactin is over-represented in E. coli isolated from CRC patients [94]. These data suggest that colibactin is a carcinogenic toxin. Besides, there are also other toxins produced by E. coli, such as CDT that can induce a remarkable cell distension, leading eventually to cell death [95]; cytotoxic necrotizing factor (Cnf) that induce dysfunctions in transformed epithelial cells [96]; and cycle inhibiting factor (Cif) that induces the formation of stress fibers and blocks cell cycle G2/M transition [97]. Because not all E. coli produce toxins, the carcinogenicity of $E$. coli may depend specifically on the levels of toxin gene rather than the total E. coli abundance. The toxins genes of E. coli are thus more suitable as CRC biomarker than intact E. coli.

\subsection{Bacteria Correlated with CRC in Firmicutes Phylum}

\subsubsection{Streptococcus}

Streptococcus is a Gram-positive, facultative anaerobic or obligate anaerobic, non-motile and roundor ovoid- shaped bacterium (Table 3). It is widely present in nasopharynx of healthy human, with most of them being non-pathogenic. Many studies have demonstrated that Streptococcus is more abundant in the intestines of CRC patients than healthy individuals [33,35,46,47]. Besides, the abundance of Streptococcus in the CRC tissues is higher than that of adjacent non-cancer tissues (Table 2) [36]. These evidences suggest that Streptococcus is likely involved in the development of CRC.

S. gallolyticus subsp. gallolyticus, which is also known as Streptococcus bovis biotype I, bears a strong association between invasive infections with S. gallolyticus and CRC by meta-analysis in clinical practice [98]. Through investigating the relationship between the subtypes of $S$. bovis and CRC, the authors found that there are $71 \%$ association between S. gallolyticus and CRC and $17 \%$ association between $S$. bovis biotype II bacteraemia and CRC [99]. These evidences suggest that the relationship between Streptococcus and CRC is mainly caused by S. gallolyticus.

The molecular mechanism of $S$. gallolyticus colonization on CRC tissues has also been revealed. By assessing the ability of 17 species of $S$. bovis group to adhere to components of the extracellular matrix in vitro, Sillanpaa et al. found that $S$. gallolyticus exhibits stronger binding ability to collagens I and IV than S. bovis [59] (Table 4). Importantly, collagen IV is the main components of basement membrane of colon mucosa in the lamina propria mucosae [100] and is highly expressed in the desmoplasia of CRC liver metastases patients [60], but type IV collagenases (MMP-2 and MMP-9) are significantly up-regulated in the basement membrane during CRC development, leading to collagen IV degradation [101]. Collagen I is increased in serum and tissues of CRC patients, which is dynamically changed during stages I-IV of CRC, with the maximum expression in stage II (Figure 2c) [61]. S. gallolyticus produces a bacteriocin (gallocin) to kill Enterococcus and help it gain a more favorable environment. Additionally, the bacteriocin can be enhanced by bile acids, which is significantly increased in CRC patient [102]. These studies seem to explain the enrichment of S. gallolyticus in CRC tissues.

S. gallolyticus can accelerate the development of CRC, and Abdulamir et al. found that S. gallolyticus may aggravate the tumor microenvironment through inflammatory factors such as cyclooxygenase-2 (COX-2), IL-1 and IL-8, followed by accelerated CRC development (Figure 1g) [103]. After co-incubating 
CRC cells with S. gallolyticus, the authors found that CRC cells exhibit increasing levels of c-Myc, $\beta$-catenin, and proliferating cell nuclear antigen to promote colon tumor development, leading to larger tumors and dysplasia grade in CRC mouse model [104].

These results demonstrate that $S$. gallolyticus can accumulate in the tumor microenvironment and accelerate the development of CRC. Therefore, as a carcinogenic bacterium, it may also serve as a new target for CRC treatment.

\subsubsection{Clostridium}

Clostridium is a Gram-positive, anaerobic, motile and rod-shaped bacterium (Table 3). They produce spores and are highly resistant to the outside environment. It mainly resides in the human intestine, and some studies indicate that the abundance of Clostridium in the intestines of CRC patients is higher than that of healthy individuals $[31,32,46]$. Further, Clostridium population is significant enhanced in the CRC tissues compared to the adjacent non-cancer tissues (Table 2) [44]. In a test group including 781 subjects, the authors found that the abundance of $C$. symbiosum gradually increases from the colorectal adenoma (CRA), early CRC, to advanced CRC [105]. The abundance of C. symbiosum and the fecal immunochemical test have also been used in combination to diagnose early CRC [105].

Several mechanisms have been proposed for Clostridium colonization (Table 4): (1) A cell biology experiment demonstrated that the adhesin Cwp66 protein in C. difficile can bind to Vero cells [63]; (2) The surface-layer protein A (SlpA), which is the most abundant protein of the S-layer, can significantly affect the adhering of $C$. difficile to intestinal epithelial cells, and $C$. difficile with different subtypes of SlpA is found to exhibit different adhesion abilities [62]; (3) Fbp68, which is located on the surface of $C$. difficile, can bind to fibronectin to play an important role for the $C$. difficile adherence to initiate infection [64]; (4) Collagen binding protein A (CbpA), which exhibits a high affinity to both collagen $\mathrm{I}$ and collagen $\mathrm{V}$, is also found to contribute to the colonization of $C$. difficile on the intestine [106]. Because the abundance of collagens I is increased in serum and tissues of CRC patients, CbpA may be one of the key factors for the accumulation of $C$. difficile in CRC tissues (Figure 2c).

Clostridium comprises not only pathogenic bacteria that promote CRC development but also probiotics that inhibit CRC development. Indeed, C. septicum produces $\alpha$-toxin that induces apoptosis in neutrophils in the tumor microenvironment, thereby down-regulating tumor immune response and accelerating CRC development (Figure 1h) [107]. Meanwhile, C. difficile secretes two toxins, TcdA and TcdB, which inactivate Rho GTPase to interrupt cell-to-cell connection and increase permeability of the intestinal barrier. Moreover, TcdA and TcdB can stimulate epithelial cells and immune cells to secrete cytokines such as TNF, IL-1, IL-5, and IL-8 to activate inflammatory responses [108]. However, C. butyricum, a butyrate-producing probiotic, can relieve intestinal inflammation, improve immune homeostasis, and inhibit CRC development in mice [109]. In addition, C. butyricum can improve the intestinal microbiota composition and suppress the Wnt/ $\beta$-catenin signaling pathway, significantly inhibiting the development of CRC in $\mathrm{Apc}^{\mathrm{Min} /+}$ mice [110].

These results indicate that some of Clostridium can promote CRC development, while others instead inhibit CRC development. How to reduce the pathogenic effect of Clostridium and increase the beneficial effect of Clostridium in the intestines of CRC patients will be a new strategy for treating CRC.

\subsubsection{Parvimonas}

Parvimonas is a Gram-positive, obligate anaerobic, non-motile and round-shaped bacterium (Table 3), which is frequently found in the human oral cavity. It is enriched in CRC and oral cancer patients, with its abundance in the intestines of CRC patients being higher than in healthy individuals $[33,45,46]$. In the CRC patients, Parvimonas exhibits higher abundance in CRC tissues compared to adjacent non-cancer tissues (Table 2) [30,44].

So far, there are few reports referring to the correlation between Parvimonas and CRC, and there is also no animal or cell biology experiment to prove that Parvimonas can cause cancer or accelerate 
the development of cancer. The mechanism by which Parvimonas is enriched in CRC tissues remains unclear and need to be further studied.

\subsubsection{Peptostreptococcus}

Peptostreptococcus is a Gram-positive, obligate anaerobic, nonmotile and spherical- or oval- shaped bacterium (Table 3), which is found in human oral cavity, upper respiratory tract, intestine, and female reproductive tract. Peptostreptococcus is considered to be a carcinogenic bacterium that promotes the development of CRC, and many studies have found that the abundance of Peptostreptococcus in the intestines of CRC patients is higher than that of healthy individuals [32,33,35,36,42,46]. In CRC patients, Peptostreptococcus also exhibits higher abundance in CRC tissues compared to adjacent non-cancer tissues (Table 2) [30,44].

Long et al. first recognized the molecular mechanism of $P$. anaerobius enrichment in CRC tissues. They identified a surface protein of P. anaerobius, PCWBR2, which can directly interact with the colorectal epithelial cell via $\alpha 2 / \beta 1$ integrin that is frequently overexpressed in CRC tissues (Figure $2 \mathrm{~d}$, Table 4). This data confirms that $P$. anaerobius is selectively enriched in CRC tissues. Further, interaction between $\alpha 2 / \beta 1$ integrin and PCWBR2 can activate the PI3K-Akt pathway in CRC cells, leading to the activation of NF- $\mathrm{KB}$ and enhanced cell proliferation that subsequently accelerates the development of CRC [65]. Besides, P. anaerobius can enhance intestinal dysplasia in mice treated with azoxymethane, because P. anaerobius interacts with both TLR2 and TLR4, and such reactions increase the level of intracellular reactive oxidative species, to promote the cholesterol synthesis and cell proliferation, finally leading to accelerated cancer development [111]. These results show that P. anaerobius can be enriched in the tumor microenvironment and participate in the development of CRC.

\section{Conclusions and Prospects}

If the battle between human and CRC is a "prolonged war", the tumor microenvironment would be the front line of the battlefield. Are the bacteria that enriched in tumor microenvironment foes or friends? Identification and clarification of the relationship between these bacteria and CRC development are extremely important.

In this review, we focused on the analyses of twelve genera that are enriched in the tumor microenvironment of CRC patients and explored their relationship with CRC development. These bacteria can be divided into three groups: (1) Direct carcinogenic bacteria, like F. nucleatum, S. gallolyticus, C. difficile, and P. anaerobius. Scientists have proposed the potential mechanism of their enrichment in CRC microenvironment, and found that these bacteria can directly participate CRC development; (2) Indirect carcinogenic bacteria, like enterotoxigenic B. fragile and E. coli. They act indirectly to impact CRC pathogenesis via secondary metabolites, or induction of immune changes in the tumor microenvironment. B. fragile and E. coli are such bacteria that are not specifically enriched in the tumor microenvironment, but the toxins they produced can promote the development of CRC; (3) Anticancer probiotics, like A. muciniphila. They do not promote development of CRC and are beneficial to human health.

We conclude that there are three mechanisms for bacteria to affect CRC development: (1) They stimulate the immune system and thereby trigger chronic inflammation. Processes in chronic inflammation might cause or facilitate epithelial cell hyper-proliferation, oncogene activation, and angiogenesis; (2) They directly or indirectly damage host DNA. Occasionally, DNA damage surpasses the host cell repair capacity, and such incomplete DNA repair would result in mutagenesis and genomic instability, leading to CRC initiation and development; (3) They affect cell proliferation and cellular apoptosis through activation of NF- $\mathrm{BB}$ or $\beta$-catenin signaling. This could promote tumor development by regulating the expression of anti-apoptotic, cell cycle or pro-inflammatory proteins. Bacteria could bind E-cadherin on the colonic epithelial cells and triggered $\beta$-catenin activation, resulting in dysregulated cell growth to acquire stem cell-like qualities. 
The bacteria enriched in tumor microenvironment have many known or potential application prospects for the CRC diagnosis, prevention, and treatment, including: (1) For strains enriched in the intestines of CRC patients, they can be regarded as biomarkers, and it is possible to develop a diagnostic method for CRC, such as qPCR and other cheap and fast methods to detect the abundance of these bacteria in the patients' feces to screen for high-risk CRC population; (2) For carcinogenic bacteria enriched in CRC, drugs against them can be developed to reduce its abundance in CRC patients, thus inhibiting the CRC development; (3) For probiotics that are colonized in the tumor microenvironment, one can increase their abundance in the intestines with oral supplements to improve CRC patients' health. These can be enclosed and supplied in a specific CRC drug delivery vehicle to target the tumor site of CRC, release cancer treatment drugs, and exert their probiotic effect.

In the future, more research on the CRC and intestinal bacteria, standardized analysis, and CRC mouse models are required to better understand how these bacteria can be used to efficiently prevent or treat CRC. If we can clearly understand the relationship between these bacteria and CRC development, we can also use bacteriophages, targeted antibiotics or even develop new vaccines to fight against these bacteria to develop new strategies for the CRC treatment.

Author Contributions: S.X. and W.Y. wrote the manuscript and added valuable insights into the manuscript. Y.Z. coordinated to write the manuscript. Q.L. participated in drafting the figures. Y.Y. searched for references. J.H. developed the concept, designed the thought and revised the manuscript. All authors have read and agreed to the published version of the manuscript.

Funding: This research was funded by the National Key Research and Development Program of China (grant 2018YFD0500204), the National Natural Science Foundation of China (grants 31970074 and 31770087), the Fundamental Research Funds for the Central Universities (grants 2662017PY112).

Conflicts of Interest: The authors declare no conflict of interest.

\section{References}

1. Bray, F.; Ferlay, J.; Soerjomataram, I.; Siegel, R.L.; Torre, L.A.; Jemal, A. Global cancer statistics 2018: GLOBOCAN estimates of incidence and mortality worldwide for 36 cancers in 185 countries. CA Cancer J. Clin. 2018, 68, 394-424. [CrossRef] [PubMed]

2. O'Keefe, S.J. Diet, microorganisms and their metabolites, and colon cancer. Nat. Rev. Gastroenterol. Hepatol. 2016, 13, 691-706. [CrossRef] [PubMed]

3. Ahn, J.; Sinha, R.; Pei, Z.; Dominianni, C.; Wu, J.; Shi, J.; Goedert, J.J.; Hayes, R.B.; Yang, L. Human gut microbiome and risk for colorectal cancer. J. Natl. Cancer Inst. 2013, 105, 1907-1911. [CrossRef] [PubMed]

4. M'Koma, A.E. Inflammatory bowel disease: An expanding global health problem. Clin. Med. Insights Gastroenterol. 2013, 6, 33-47. [CrossRef]

5. Zhiqin, W.; Palaniappan, S.; Raja Ali, R.A. Inflammatory bowel disease-related colorectal cancer in the Asia-Pacific region: Past, present, and future. Intest. Res. 2014, 12, 194-204. [CrossRef]

6. Abraham, C.; Medzhitov, R. Interactions between the host innate immune system and microbes in inflammatory bowel disease. Gastroenterology 2011, 140, 1729-1737. [CrossRef]

7. Arthur, J.C.; Gharaibeh, R.Z.; Muhlbauer, M.; Perez-Chanona, E.; Uronis, J.M.; McCafferty, J.; Fodor, A.A.; Jobin, C. Microbial genomic analysis reveals the essential role of inflammation in bacteria-induced colorectal cancer. Nat. Commun. 2014, 5, 4724. [CrossRef]

8. Ye, L.; Cao, Q.; Cheng, J. Review of inflammatory bowel disease in China. Sci. World J. 2013, 2013, 296470. [CrossRef]

9. Gordon, J.I. Honor thy gut symbionts redux. Science 2012, 336, 1251-1253. [CrossRef]

10. O'Hara, A.M.; Shanahan, F. The gut flora as a forgotten organ. EMBO Rep. 2006, 7, 688-693. [CrossRef]

11. Qin, J.; Li, R.; Raes, J.; Arumugam, M.; Burgdorf, K.S.; Manichanh, C.; Nielsen, T.; Pons, N.; Levenez, F.; Yamada, T.; et al. A human gut microbial gene catalogue established by metagenomic sequencing. Nature 2010, 464, 59-65. [CrossRef]

12. Komaroff, A.L. The microbiome and risk for obesity and diabetes. JAMA 2017, 317, 355-356. [CrossRef] 
13. Koh, A.; Molinaro, A.; Stahlman, M.; Khan, M.T.; Schmidt, C.; Manneras-Holm, L.; Wu, H.; Carreras, A.; Jeong, H.; Olofsson, L.E.; et al. Microbially produced imidazole propionate impairs insulin signaling through mTORC1. Cell 2018, 175, 947-961. [CrossRef]

14. Yuan, J.; Chen, C.; Cui, J.; Lu, J.; Yan, C.; Wei, X.; Zhao, X.; Li, N.; Li, S.; Xue, G.; et al. Fatty liver disease caused by high-alcohol-producing Klebsiella pneumoniae. Cell Metab. 2019, 30, 675-688. [CrossRef]

15. Wilck, N.; Matus, M.G.; Kearney, S.M.; Olesen, S.W.; Forslund, K.; Bartolomaeus, H.; Haase, S.; Mahler, A.; Balogh, A.; Marko, L.; et al. Salt-responsive gut commensal modulates TH17 axis and disease. Nature 2017, 551, 585-589. [CrossRef]

16. Allen, J.; Sears, C.L. Impact of the gut microbiome on the genome and epigenome of colon epithelial cells: Contributions to colorectal cancer development. Genome Med. 2019, 11, 11. [CrossRef]

17. Flint, H.J.; Scott, K.P.; Louis, P.; Duncan, S.H. The role of the gut microbiota in nutrition and health. Nat. Rev. Gastroenterol. Hepatol. 2012, 9, 577-589. [CrossRef]

18. Rajilic-Stojanovic, M.; de Vos, W.M. The first 1000 cultured species of the human gastrointestinal microbiota. FEMS Microbiol. Rev. 2014, 38, 996-1047. [CrossRef]

19. Castellarin, M.; Warren, R.L.; Freeman, J.D.; Dreolini, L.; Krzywinski, M.; Strauss, J.; Barnes, R.; Watson, P.; Allen-Vercoe, E.; Moore, R.A.; et al. Fusobacterium nucleatum infection is prevalent in human colorectal carcinoma. Genome Res. 2012, 22, 299-306. [CrossRef]

20. Kostic, A.D.; Chun, E.; Robertson, L.; Glickman, J.N.; Gallini, C.A.; Michaud, M.; Clancy, T.E.; Chung, D.C.; Lochhead, P.; Hold, G.L.; et al. Fusobacterium nucleatum potentiates intestinal tumorigenesis and modulates the tumor-immune microenvironment. Cell Host Microbe 2013, 14, 207-215. [CrossRef]

21. Mira-Pascual, L.; Cabrera-Rubio, R.; Ocon, S.; Costales, P.; Parra, A.; Suarez, A.; Moris, F.; Rodrigo, L.; Mira, A.; Collado, M.C. Microbial mucosal colonic shifts associated with the development of colorectal cancer reveal the presence of different bacterial and archaeal biomarkers. J. Gastroenterol. 2015, 50, 167-179. [CrossRef]

22. Wei, H.; Dong, L.; Wang, T.; Zhang, M.; Hua, W.; Zhang, C.; Pang, X.; Chen, M.; Su, M.; Qiu, Y.; et al. Structural shifts of gut microbiota as surrogate endpoints for monitoring host health changes induced by carcinogen exposure. FEMS Microbiol. Ecol. 2010, 73, 577-586. [CrossRef]

23. Tjalsma, H.; Boleij, A.; Marchesi, J.R.; Dutilh, B.E. A bacterial driver-passenger model for colorectal cancer: Beyond the usual suspects. Nat. Rev. Microbiol. 2012, 10, 575-582. [CrossRef]

24. Dejea, C.M.; Fathi, P.; Craig, J.M.; Boleij, A.; Taddese, R.; Geis, A.L.; Wu, X.; DeStefano Shields, C.E.; Hechenbleikner, E.M.; Huso, D.L.; et al. Patients with familial adenomatous polyposis harbor colonic biofilms containing tumorigenic bacteria. Science 2018, 359, 592-597. [CrossRef]

25. Pons, B.J.; Vignard, J.; Mirey, G. Cytolethal Distending Toxin Subunit B: A review of structure-function relationship. Toxins (Basel) 2019, 11, 595. [CrossRef]

26. Rubinstein, M.R.; Wang, X.; Liu, W.; Hao, Y.; Cai, G.; Han, Y.W. Fusobacterium nucleatum promotes colorectal carcinogenesis by modulating E-cadherin/ $\beta$-catenin signaling via its FadA adhesin. Cell Host Microbe 2013, 14, 195-206. [CrossRef]

27. Routy, B.; Le Chatelier, E.; Derosa, L.; Duong, C.P.M.; Alou, M.T.; Daillere, R.; Fluckiger, A.; Messaoudene, M.; Rauber, C.; Roberti, M.P.; et al. Gut microbiome influences efficacy of PD-1-based immunotherapy against epithelial tumors. Science 2018, 359, 91-97. [CrossRef]

28. Zhang, H.; Chang, Y.; Zheng, Q.; Zhang, R.; Hu, C.; Jia, W. Altered intestinal microbiota associated with colorectal cancer. Front. Med. 2019, 13, 461-470. [CrossRef]

29. Saffarian, A.; Mulet, C.; Regnault, B.; Amiot, A.; Tran-Van-Nhieu, J.; Ravel, J.; Sobhani, I.; Sansonetti, P.J.; Pedron, T. Crypt- and mucosa-associated core microbiotas in humans and their alteration in colon cancer patients. Microbiology 2019, 10, e01315-e01319. [CrossRef]

30. Gao, R.; Kong, C.; Huang, L.; Li, H.; Qu, X.; Liu, Z.; Lan, P.; Wang, J.; Qin, H. Mucosa-associated microbiota signature in colorectal cancer. Eur. J. Clin. Microbiol. Infect. Dis. 2017, 36, 2073-2083. [CrossRef]

31. Thomas, A.M.; Jesus, E.C.; Lopes, A.; Aguiar, S., Jr.; Begnami, M.D.; Rocha, R.M.; Carpinetti, P.A.; Camargo, A.A.; Hoffmann, C.; Freitas, H.C.; et al. Tissue-associated bacterial alterations in rectal carcinoma patients revealed by $16 \mathrm{~S}$ rRNA community profiling. Front. Cell Infect. Microbiol. 2016, 6, 179. [CrossRef]

32. Allali, I.; Boukhatem, N.; Bouguenouch, L.; Hardi, H.; Boudouaya, H.A.; Cadenas, M.B.; Ouldim, K.; Amzazi, S.; Azcarate-Peril, M.A.; Ghazal, H. Gut microbiome of Moroccan colorectal cancer patients. Med. Microbiol. Immunol. 2018, 207, 211-225. [CrossRef] 
33. Flemer, B.; Lynch, D.B.; Brown, J.M.; Jeffery, I.B.; Ryan, F.J.; Claesson, M.J.; O’Riordain, M.; Shanahan, F.; O'Toole, P.W. Tumour-associated and non-tumour-associated microbiota in colorectal cancer. Gut 2017, 66, 633-643. [CrossRef]

34. Weir, T.L.; Manter, D.K.; Sheflin, A.M.; Barnett, B.A.; Heuberger, A.L.; Ryan, E.P. Stool microbiome and metabolome differences between colorectal cancer patients and healthy adults. PLOS ONE 2013, 8, e70803. [CrossRef]

35. Wang, T.; Cai, G.; Qiu, Y.; Fei, N.; Zhang, M.; Pang, X.; Jia, W.; Cai, S.; Zhao, L. Structural segregation of gut microbiota between colorectal cancer patients and healthy volunteers. ISME J. 2012, 6, 320-329. [CrossRef]

36. Gao, Z.; Guo, B.; Gao, R.; Zhu, Q.; Qin, H. Microbiota disbiosis is associated with colorectal cancer. Front. Microbiol. 2015, 6, 20. [CrossRef]

37. Allali, I.; Delgado, S.; Marron, P.I.; Astudillo, A.; Yeh, J.J.; Ghazal, H.; Amzazi, S.; Keku, T.; Azcarate-Peril, M.A. Gut microbiome compositional and functional differences between tumor and non-tumor adjacent tissues from cohorts from the US and Spain. Gut Microbes 2015, 6, 161-172. [CrossRef]

38. Wu, N.; Yang, X.; Zhang, R.; Li, J.; Xiao, X.; Hu, Y.; Chen, Y.; Yang, F.; Lu, N.; Wang, Z.; et al. Dysbiosis signature of fecal microbiota in colorectal cancer patients. Microb. Ecol. 2013, 66, 462-470. [CrossRef]

39. Geng, J.; Fan, H.; Tang, X.; Zhai, H.; Zhang, Z. Diversified pattern of the human colorectal cancer microbiome. Gut Pathog. 2013, 5, 2. [CrossRef]

40. Youssef, O.; Lahti, L.; Kokkola, A.; Karla, T.; Tikkanen, M.; Ehsan, H.; Carpelan-Holmstrom, M.; Koskensalo, S.; Bohling, T.; Rautelin, H.; et al. Stool microbiota composition differs in patients with stomach, colon, and rectal neoplasms. Dig. Dis. Sci. 2018, 63, 2950-2958. [CrossRef]

41. Sobhani, I.; Tap, J.; Roudot-Thoraval, F.; Roperch, J.P.; Letulle, S.; Langella, P.; Corthier, G.; Tran Van Nhieu, J.; Furet, J.P. Microbial dysbiosis in colorectal cancer (CRC) patients. PLoS ONE 2011, 6, e16393. [CrossRef] [PubMed]

42. Chen, W.; Liu, F.; Ling, Z.; Tong, X.; Xiang, C. Human intestinal lumen and mucosa-associated microbiota in patients with colorectal cancer. PLoS ONE 2012, 7, e39743. [CrossRef] [PubMed]

43. Kostic, A.D.; Gevers, D.; Pedamallu, C.S.; Michaud, M.; Duke, F.; Earl, A.M.; Ojesina, A.I.; Jung, J.; Bass, A.J.; Tabernero, J.; et al. Genomic analysis identifies association of Fusobacterium with colorectal carcinoma. Genome Res. 2012, 22, 292-298. [CrossRef] [PubMed]

44. de Carvalho, A.C.; de Mattos Pereira, L.; Datorre, J.G.; Dos Santos, W.; Berardinelli, G.N.; Matsushita, M.M.; Oliveira, M.A.; Duraes, R.O.; Guimaraes, D.P.; Reis, R.M. Microbiota profile and impact of Fusobacterium nucleatum in colorectal cancer patients of Barretos cancer hospital. Front. Oncol. 2019, 9, 813. [CrossRef]

45. Yang, Y.; Misra, B.B.; Liang, L.; Bi, D.; Weng, W.; Wu, W.; Cai, S.; Qin, H.; Goel, A.; Li, X.; et al. Integrated microbiome and metabolome analysis reveals a novel interplay between commensal bacteria and metabolites in colorectal cancer. Theranostics 2019, 9, 4101-4114. [CrossRef]

46. Xu, K.; Jiang, B. Analysis of mucosa-associated microbiota in colorectal cancer. Med. Sci. Monit. 2017, 23, 4422-4430. [CrossRef]

47. Geng, J.; Song, Q.; Tang, X.; Liang, X.; Fan, H.; Peng, H.; Guo, Q.; Zhang, Z. Co-occurrence of driver and passenger bacteria in human colorectal cancer. Gut Pathog. 2014, 6, 26. [CrossRef]

48. Lee, S.M.; Donaldson, G.P.; Mikulski, Z.; Boyajian, S.; Ley, K.; Mazmanian, S.K. Bacterial colonization factors control specificity and stability of the gut microbiota. Nature 2013, 501, 426-429. [CrossRef]

49. Donaldson, G.P.; Ladinsky, M.S.; Yu, K.B.; Sanders, J.G.; Yoo, B.B.; Chou, W.C.; Conner, M.E.; Earl, A.M.; Knight, R.; Bjorkman, P.J.; et al. Gut microbiota utilize immunoglobulin A for mucosal colonization. Science 2018, 360, 795-800. [CrossRef]

50. Shiryaev, S.A.; Remacle, A.G.; Cieplak, P.; Strongin, A.Y. Peptide sequence region that is essential for the interactions of the enterotoxigenic Bacteroides fragilis metalloproteinase II with E-cadherin. J. Proteolysis 2014, 1, 3-14.

51. Abed, J.; Emgard, J.E.; Zamir, G.; Faroja, M.; Almogy, G.; Grenov, A.; Sol, A.; Naor, R.; Pikarsky, E.; Atlan, K.A.; et al. Fap2 mediates Fusobacterium nucleatum colorectal adenocarcinoma enrichment by binding to tumor-expressed Gal-GalNAc. Cell Host Microbe 2016, 20, 215-225. [CrossRef]

52. Byrd, J.C.; Bresalier, R.S. Mucins and mucin binding proteins in colorectal cancer. Cancer Metastasis. Rev. 2004, 23, 77-99. [CrossRef] 
53. Schmidt, A.M.; Escher, U.; Mousavi, S.; Tegtmeyer, N.; Boehm, M.; Backert, S.; Bereswill, S.; Heimesaat, M.M. Immunopathological properties of the Campylobacter jejuni flagellins and the adhesin CadF as assessed in a clinical murine infection model. Gut Pathog. 2019, 11, 24. [CrossRef]

54. Konkel, M.E.; Larson, C.L.; Flanagan, R.C. Campylobacter jejuni FlpA binds fibronectin and is required for maximal host cell adherence. J. Bacteriol. 2010, 192, 68-76. [CrossRef]

55. Pei, Z.; Burucoa, C.; Grignon, B.; Baqar, S.; Huang, X.Z.; Kopecko, D.J.; Bourgeois, A.L.; Fauchere, J.L.; Blaser, M.J. Mutation in the peb1A locus of Campylobacter jejuni reduces interactions with epithelial cells and intestinal colonization of mice. Infect. Immun. 1998, 66, 938-943. [CrossRef]

56. Freitag, C.M.; Strijbis, K.; van Putten, J.P.M. Host cell binding of the flagellar tip protein of Campylobacter jejuni. Cell. Microbiol. 2017, 19. [CrossRef]

57. Maddocks, O.D.; Short, A.J.; Donnenberg, M.S.; Bader, S.; Harrison, D.J. Attaching and effacing Escherichia coli downregulate DNA mismatch repair protein in vitro and are associated with colorectal adenocarcinomas in humans. PLoS ONE 2009, 4, e5517. [CrossRef]

58. Prorok-Hamon, M.; Friswell, M.K.; Alswied, A.; Roberts, C.L.; Song, F.; Flanagan, P.K.; Knight, P.; Codling, C.; Marchesi, J.R.; Winstanley, C.; et al. Colonic mucosa-associated diffusely adherent afaC ${ }^{+}$Escherichia coli expressing $\operatorname{lpf} A$ and $p k s$ are increased in inflammatory bowel disease and colon cancer. Gut 2014, 63, 761-770. [CrossRef]

59. Sillanpaa, J.; Nallapareddy, S.R.; Singh, K.V.; Ferraro, M.J.; Murray, B.E. Adherence characteristics of endocarditis-derived Streptococcus gallolyticus ssp. gallolyticus (Streptococcus bovis biotype I) isolates to host extracellular matrix proteins. FEMS Microbiol. Lett. 2008, 289, 104-109. [CrossRef]

60. Nystrom, H.; Naredi, P.; Hafstrom, L.; Sund, M. Type IV collagen as a tumour marker for colorectal liver metastases. Eur. J. Surg. Oncol. 2011, 37, 611-617. [CrossRef]

61. Zou, X.; Feng, B.; Dong, T.; Yan, G.; Tan, B.; Shen, H.; Huang, A.; Zhang, X.; Zhang, M.; Yang, P.; et al. Up-regulation of type I collagen during tumorigenesis of colorectal cancer revealed by quantitative proteomic analysis. J. Proteomics 2013, 94, 473-485. [CrossRef]

62. Merrigan, M.M.; Venugopal, A.; Roxas, J.L.; Anwar, F.; Mallozzi, M.J.; Roxas, B.A.; Gerding, D.N.; Viswanathan, V.K.; Vedantam, G. Surface-layer protein A (SlpA) is a major contributor to host-cell adherence of Clostridium difficile. PLoS ONE 2013, 8, e78404. [CrossRef]

63. Waligora, A.J.; Hennequin, C.; Mullany, P.; Bourlioux, P.; Collignon, A.; Karjalainen, T. Characterization of a cell surface protein of Clostridium difficile with adhesive properties. Infect. Immun. 2001, 69, 2144-2153. [CrossRef]

64. Lin, Y.P.; Kuo, C.J.; Koleci, X.; McDonough, S.P.; Chang, Y.F. Manganese binds to Clostridium difficile Fbp68 and is essential for fibronectin binding. J. Biol. Chem. 2011, 286, 3957-3969. [CrossRef]

65. Long, X.; Wong, C.C.; Tong, L.; Chu, E.S.H.; Ho Szeto, C.; Go, M.Y.Y.; Coker, O.O.; Chan, A.W.H.; Chan, F.K.L.; Sung, J.J.Y.; et al. Peptostreptococcus anaerobius promotes colorectal carcinogenesis and modulates tumour immunity. Nat. Microbiol. 2019, 4, 2319-2330. [CrossRef]

66. Sears, C.L. Enterotoxigenic Bacteroides fragilis: A rogue among symbiotes. Clin. Microbiol. Rev. 2009, 22, 349-369. [CrossRef]

67. Boleij, A.; Hechenbleikner, E.M.; Goodwin, A.C.; Badani, R.; Stein, E.M.; Lazarev, M.G.; Ellis, B.; Carroll, K.C.; Albesiano, E.; Wick, E.C.; et al. The Bacteroides fragilis toxin gene is prevalent in the colon mucosa of colorectal cancer patients. Clin. Infect. Dis. 2015, 60, 208-215. [CrossRef]

68. Chung, L.; Thiele Orberg, E.; Geis, A.L.; Chan, J.L.; Fu, K.; DeStefano Shields, C.E.; Dejea, C.M.; Fathi, P.; Chen, J.; Finard, B.B.; et al. Bacteroides fragilis toxin coordinates a pro-carcinogenic inflammatory cascade via targeting of colonic epithelial cells. Cell Host Microbe 2018, 23, 203-214. [CrossRef]

69. Kim, J.M.; Jung, H.Y.; Lee, J.Y.; Youn, J.; Lee, C.H.; Kim, K.H. Mitogen-activated protein kinase and activator protein-1 dependent signals are essential for Bacteroides fragilis enterotoxin-induced enteritis. Eur. J. Immunol. 2005, 35, 2648-2657. [CrossRef]

70. Goodwin, A.C.; Destefano Shields, C.E.; Wu, S.; Huso, D.L.; Wu, X.; Murray-Stewart, T.R.; Hacker-Prietz, A.; Rabizadeh, S.; Woster, P.M.; Sears, C.L.; et al. Polyamine catabolism contributes to enterotoxigenic Bacteroides fragilis-induced colon tumorigenesis. Proc. Natl. Acad. Sci. USA 2011, 108, 15354-15359. [CrossRef]

71. Holden, J.A.; O’Brien-Simpson, N.M.; Lenzo, J.C.; Orth, R.K.H.; Mansell, A.; Reynolds, E.C. Porphyromonas gulae activates unprimed and gamma interferon-primed macrophages via the pattern recognition receptors Toll-Like Receptor 2 (TLR2), TLR4, and NOD2. Infect. Immun. 2017, 85, e0282-17. [CrossRef] 
72. Holden, J.A.; Attard, T.J.; Laughton, K.M.; Mansell, A.; O’Brien-Simpson, N.M.; Reynolds, E.C. Porphyromonas gingivalis lipopolysaccharide weakly activates M1 and M2 polarized mouse macrophages but induces inflammatory cytokines. Infect. Immun. 2014, 82, 4190-4203. [CrossRef]

73. Nosho, K.; Sukawa, Y.; Adachi, Y.; Ito, M.; Mitsuhashi, K.; Kurihara, H.; Kanno, S.; Yamamoto, I.; Ishigami, K.; Igarashi, H.; et al. Association of Fusobacterium nucleatum with immunity and molecular alterations in colorectal cancer. World J. Gastroenterol. 2016, 22, 557-566. [CrossRef]

74. Mitsuhashi, K.; Nosho, K.; Sukawa, Y.; Matsunaga, Y.; Ito, M.; Kurihara, H.; Kanno, S.; Igarashi, H.; Naito, T.; Adachi, Y.; et al. Association of Fusobacterium species in pancreatic cancer tissues with molecular features and prognosis. Oncotarget 2015, 6, 7209-7220. [CrossRef]

75. Han, Y.W.; Redline, R.W.; Li, M.; Yin, L.; Hill, G.B.; McCormick, T.S. Fusobacterium nucleatum induces premature and term stillbirths in pregnant mice: Implication of oral bacteria in preterm birth. Infect. Immun. 2004, 72, 2272-2279. [CrossRef]

76. Yu, T.; Guo, F.; Yu, Y.; Sun, T.; Ma, D.; Han, J.; Qian, Y.; Kryczek, I.; Sun, D.; Nagarsheth, N.; et al. Fusobacterium nucleatum promotes chemoresistance to colorectal cancer by modulating autophagy. Cell 2017, 170, 548-563. [CrossRef]

77. Gur, C.; Ibrahim, Y.; Isaacson, B.; Yamin, R.; Abed, J.; Gamliel, M.; Enk, J.; Bar-On, Y.; Stanietsky-Kaynan, N.; Coppenhagen-Glazer, S.; et al. Binding of the Fap2 protein of Fusobacterium nucleatum to human inhibitory receptor TIGIT protects tumors from immune cell attack. Immunity 2015, 42, 344-355. [CrossRef]

78. Eribe, E.R.K.; Olsen, I. Leptotrichia species in human infections II. J. Oral Microbiol. 2017, 9, 1368848. [CrossRef]

79. Kim, K.; Castro, E.J.T.; Shim, H.; Advincula, J.V.G.; Kim, Y.W. Differences regarding the molecular features and gut microbiota between right and left colon cancer. Ann. Coloproctol. 2018, 34, 280-285. [CrossRef]

80. Derrien, M.; Collado, M.C.; Ben-Amor, K.; Salminen, S.; de Vos, W.M. The Mucin degrader Akkermansia muciniphila is an abundant resident of the human intestinal tract. Appl. Environ. Microbiol. 2008, 74, 1646-1648. [CrossRef]

81. Derrien, M.; Belzer, C.; de Vos, W.M. Akkermansia muciniphila and its role in regulating host functions. Microb. Pathog. 2017, 106, 171-181. [CrossRef]

82. Hanninen, A.; Toivonen, R.; Poysti, S.; Belzer, C.; Plovier, H.; Ouwerkerk, J.P.; Emani, R.; Cani, P.D.; De Vos, W.M. Akkermansia muciniphila induces gut microbiota remodelling and controls islet autoimmunity in NOD mice. Gut 2018, 67, 1445-1453. [CrossRef]

83. Grander, C.; Adolph, T.E.; Wieser, V.; Lowe, P.; Wrzosek, L.; Gyongyosi, B.; Ward, D.V.; Grabherr, F.; Gerner, R.R.; Pfister, A.; et al. Recovery of ethanol-induced Akkermansia muciniphila depletion ameliorates alcoholic liver disease. Gut 2018, 67, 891-901. [CrossRef]

84. Barcena, C.; Valdes-Mas, R.; Mayoral, P.; Garabaya, C.; Durand, S.; Rodriguez, F.; Fernandez-Garcia, M.T.; Salazar, N.; Nogacka, A.M.; Garatachea, N.; et al. Healthspan and lifespan extension by fecal microbiota transplantation into progeroid mice. Nat. Med. 2019, 25, 1234-1242. [CrossRef]

85. Depommier, C.; Everard, A.; Druart, C.; Plovier, H.; Van Hul, M.; Vieira-Silva, S.; Falony, G.; Raes, J.; Maiter, D.; Delzenne, N.M.; et al. Supplementation with Akkermansia muciniphila in overweight and obese human volunteers: A proof-of-concept exploratory study. Nat. Med. 2019, 25, 1096-1103. [CrossRef]

86. Gradel, K.O.; Nielsen, H.L.; Schonheyder, H.C.; Ejlertsen, T.; Kristensen, B.; Nielsen, H. Increased short- and long-term risk of inflammatory bowel disease after Salmonella or Campylobacter gastroenteritis. Gastroenterology 2009, 137, 495-501. [CrossRef]

87. He, Z.; Gharaibeh, R.Z.; Newsome, R.C.; Pope, J.L.; Dougherty, M.W.; Tomkovich, S.; Pons, B.; Mirey, G.; Vignard, J.; Hendrixson, D.R.; et al. Campylobacter jejuni promotes colorectal tumorigenesis through the action of cytolethal distending toxin. Gut 2019, 68, 289-300. [CrossRef]

88. Scanlan, P.D.; Shanahan, F.; Marchesi, J.R. Culture-independent analysis of Desulfovibrios in the human distal colon of healthy, colorectal cancer and polypectomized individuals. FEMS Microbiol. Ecol. 2009, 69, $213-221$. [CrossRef]

89. Szabo, C. Gasotransmitters in cancer: From pathophysiology to experimental therapy. Nat. Rev. Drug Discov. 2016, 15, 185-203. [CrossRef]

90. Kapral, M.; Weglarz, L.; Parfiniewicz, B.; Lodowska, J.; Jaworska-Kik, M. Quantitative evaluation of transcriptional activation of NF- $\mathrm{B}$ p 65 and p50 subunits and $\mathrm{I} \kappa \mathrm{B} \alpha$ encoding genes in colon cancer cells by Desulfovibrio desulfuricans endotoxin. Folia Microbiol. (Praha) 2010, 55, 657-661. [CrossRef] 
91. Buc, E.; Dubois, D.; Sauvanet, P.; Raisch, J.; Delmas, J.; Darfeuille-Michaud, A.; Pezet, D.; Bonnet, R. High prevalence of mucosa-associated E. coli producing cyclomodulin and genotoxin in colon cancer. PLoS ONE 2013, 8, e56964. [CrossRef]

92. Arthur, J.C.; Perez-Chanona, E.; Muhlbauer, M.; Tomkovich, S.; Uronis, J.M.; Fan, T.J.; Campbell, B.J.; Abujamel, T.; Dogan, B.; Rogers, A.B.; et al. Intestinal inflammation targets cancer-inducing activity of the microbiota. Science 2012, 338, 120-123. [CrossRef]

93. Cuevas-Ramos, G.; Petit, C.R.; Marcq, I.; Boury, M.; Oswald, E.; Nougayrede, J.P. Escherichia coli induces DNA damage in vivo and triggers genomic instability in mammalian cells. Proc. Natl. Acad. Sci. USA 2010, 107, 11537-11542. [CrossRef]

94. Wassenaar, T.M. E. coli and colorectal cancer: A complex relationship that deserves a critical mindset. Crit. Rev. Microbiol. 2018, 44, 619-632. [CrossRef]

95. Grasso, F.; Frisan, T. Bacterial genotoxins: Merging the DNA damage response into infection biology. Biomolecules 2015, 5, 1762-1782. [CrossRef]

96. Fabbri, A.; Travaglione, S.; Ballan, G.; Loizzo, S.; Fiorentini, C. The cytotoxic necrotizing factor 1 from E. coli: A janus toxin playing with cancer regulators. Toxins (Basel) 2013, 5, 1462-1474. [CrossRef]

97. Marches, O.; Ledger, T.N.; Boury, M.; Ohara, M.; Tu, X.; Goffaux, F.; Mainil, J.; Rosenshine, I.; Sugai, M.; De Rycke, J.; et al. Enteropathogenic and enterohaemorrhagic Escherichia coli deliver a novel effector called Cif, which blocks cell cycle G2/M transition. Mol. Microbiol. 2003, 50, 1553-1567. [CrossRef]

98. Boleij, A.; van Gelder, M.M.; Swinkels, D.W.; Tjalsma, H. Clinical importance of Streptococcus gallolyticus infection among colorectal cancer patients: Systematic review and meta-analysis. Clin. Infect. Dis. 2011, 53, 870-878. [CrossRef]

99. Abdulamir, A.S.; Hafidh, R.R.; Abu Bakar, F. The association of Streptococcus bovis/gallolyticus with colorectal tumors: The nature and the underlying mechanisms of its etiological role. J. Exp. Clin. Cancer Res. 2011, 30, 11. [CrossRef]

100. Galbavy, S.; Lukac, L.; Porubsky, J.; Cerna, M.; Labuda, M.; Kmet'ova, J.; Papincak, J.; Durdik, S.; Jakubovsky, J. Collagen type IV in epithelial tumours of colon. Acta Histochem. 2002, 104, 331-334. [CrossRef]

101. Zeng, Z.S.; Cohen, A.M.; Guillem, J.G. Loss of basement membrane type IV collagen is associated with increased expression of metalloproteinases 2 and 9 (MMP-2 and MMP-9) during human colorectal tumorigenesis. Carcinogenesis 1999, 20, 749-755. [CrossRef]

102. Aymeric, L.; Donnadieu, F.; Mulet, C.; du Merle, L.; Nigro, G.; Saffarian, A.; Berard, M.; Poyart, C.; Robine, S.; Regnault, B.; et al. Colorectal cancer specific conditions promote Streptococcus gallolyticus gut colonization. Proc. Natl. Acad. Sci. USA 2018, 115, E283-E291. [CrossRef]

103. Abdulamir, A.S.; Hafidh, R.R.; Bakar, F.A. Molecular detection, quantification, and isolation of Streptococcus gallolyticus bacteria colonizing colorectal tumors: Inflammation-driven potential of carcinogenesis via IL-1, COX-2, and IL-8. Mol. Cancer 2010, 9, 249. [CrossRef]

104. Kumar, R.; Herold, J.L.; Schady, D.; Davis, J.; Kopetz, S.; Martinez-Moczygemba, M.; Murray, B.E.; Han, F.; Li, Y.; Callaway, E.; et al. Streptococcus gallolyticus subsp. gallolyticus promotes colorectal tumor development. PLoS Pathog. 2017, 13, e1006440. [CrossRef]

105. Xie, Y.H.; Gao, Q.Y.; Cai, G.X.; Sun, X.M.; Sun, X.M.; Zou, T.H.; Chen, H.M.; Yu, S.Y.; Qiu, Y.W.; Gu, W.Q.; et al. Fecal Clostridium symbiosum for noninvasive detection of early and advanced colorectal cancer: Test and validation studies. EBioMedicine 2017, 25, 32-40. [CrossRef]

106. Tulli, L.; Marchi, S.; Petracca, R.; Shaw, H.A.; Fairweather, N.F.; Scarselli, M.; Soriani, M.; Leuzzi, R. CbpA: A novel surface exposed adhesin of Clostridium difficile targeting human collagen. Cell. Microbiol. 2013, 15, 1674-1687. [CrossRef]

107. Kennedy, C.L.; Krejany, E.O.; Young, L.F.; O'Connor, J.R.; Awad, M.M.; Boyd, R.L.; Emmins, J.J.; Lyras, D.; Rood, J.I. The $\alpha$-toxin of Clostridium septicum is essential for virulence. Mol. Microbiol. 2005, 57, 1357-1366. [CrossRef]

108. Pruitt, R.N.; Lacy, D.B. Toward a structural understanding of Clostridium difficile toxins A and B. Front. Cell. Infect. Microbiol. 2012, 2, 28. [CrossRef]

109. Chen, Z.F.; Ai, L.Y.; Wang, J.L.; Ren, L.L.; Yu, Y.N.; Xu, J.; Chen, H.Y.; Yu, J.; Li, M.; Qin, W.X.; et al. Probiotics Clostridium butyricum and Bacillus subtilis ameliorate intestinal tumorigenesis. Future Microbiol. 2015, 10, 1433-1445. [CrossRef] 
110. Chen, D.; Jin, D.; Huang, S.; Wu, J.; Xu, M.; Liu, T.; Dong, W.; Liu, X.; Wang, S.; Zhong, W.; et al. Clostridium butyricum, a butyrate-producing probiotic, inhibits intestinal tumor development through modulating Wnt signaling and gut microbiota. Cancer Lett. 2020, 469, 456-467. [CrossRef]

111. Tsoi, H.; Chu, E.S.H.; Zhang, X.; Sheng, J.; Nakatsu, G.; Ng, S.C.; Chan, A.W.H.; Chan, F.K.L.; Sung, J.J.Y.; $\mathrm{Yu}, \mathrm{J}$. Peptostreptococcus anaerobius induces intracellular cholesterol biosynthesis in colon cells to induce proliferation and causes dysplasia in mice. Gastroenterology 2017, 152, 1419-1433. [CrossRef]

(C) 2020 by the authors. Licensee MDPI, Basel, Switzerland. This article is an open access article distributed under the terms and conditions of the Creative Commons Attribution (CC BY) license (http://creativecommons.org/licenses/by/4.0/). 